\title{
Tecidos no museu: argumentos para uma história das práticas curatoriais no Brasil
}

\section{Teresa Cristina Toledo de Paula}

RESUMO: $\bigcirc$ texto apresenta alguns argumentos sobre as práticas curatoriais desenvolvidas com aqueles acervos têxteis que hoje integram as coleções da Universidade de São Paulo. As atividades de coleta, documentação, conservação, exposição e trânsito das coleções foram discutidas a partir daqueles que teriam sido os vetores/valores determinantes associados aos trabalhos curatoriais dos museus no século passado.

PALAVRAS-CHAVE: Conservação de Tecidos. Museus. Coleções. Curadoria. Museu Paulista. Museu de Arqueologia e Etnologia.

ABSTRACT: This paper forwards certain arguments related to the curatorial practices developed around the fabrics that are now part of the collections maintained by the University of São Paulo. The activities of collecting, documenting, conserving, displaying and transfering collections were discussed on the basis of what would have been the determining guidelines/values associated with the curatorial work of museums in the last century.

KEYWORDS: Conservation of textiles. Museums. Collections. Curatorship. Paulista Museum. Museum of Archeology and Ethnology.

Bem distante das chitas floridas e dos tecidos vermelhos, tintos com pau-brasil, as coleções museológicas brasileiras com tecidos formaram-se seguindo os receituários internacionais vigentes para os museus a partir de meados do século XIX e, portanto, alheias a questões de caráter e interesse locais (e talvez atuais). As coleções têxteis, mundo afora, mais especificamente aquelas de tecidos - nos termos aqui definidos ${ }^{2}-$, começaram a ser formadas a partir de 1851, quando foi inaugurado, em Londres, o South Kensington Museum, atual Victoria \& Albert Museum. Sua inauguração - declara-se consensualmente - foi a inspiração para o surgimento de vários outros museus
1. Conservadora-doutora de têxteis do Museu Paulista. E-mail: <tcpaula@ usp.br>.

Agradeço ao professor dr. Murilo Marx, então diretor do MAE/USP, ter autorizado a publicação das imagens de arquivo; a Wagner Souza e Silva (MAE/USP) pela reprodução e tratamento das imagens de arquivos utilizadas aqui e em meu doutorado; a Marilúcia Botallo pelas ponderações e ajuda na busca de imagens e registros.

2. A definição de tecido que adotamos foi: $u m$ produto flexível resultante do entrelaçamento de fios. 
3. A idéia da criação de um museu em Lyon teria sido cogitada já em 1851 , após a participação das indústrias lyonesas na Exposição Nacional de In dústria, em Paris (ARIZ ZOLI-CLÉMENTEL 1990).

4. Não dispomos, ainda hoje, de uma quantificação das coleções de tecidos espalhadas pelo mundo, mas essa matemática - nestes tempos dominados por bancos de dados - não tardará sem dúvida a aparecer. Podemos apenas constatar que coleções de tecidos existem em grandes e equivalentes quantidades tanto em museus históricos quanto em museus etnográficos.

5. O Comité Nacional de Conservación Textil no Chile foi criado em 1986 e, dentre outras atividades, realiza encontros e publicações anuais. O Museu Paulista realizou em maio de 2006 o Se minário Internacional Tecidos e sua Conservação no Brasil: Museus e Coleções, com publicação homônima

6. Em Lyon publicou-se em 1900, L'art de décorer les tissus (1900); no caso da indumentária, há registro de catálogos mais antigos na Alemanha, preparados pelos pesquisadores Karl Köhler e Max Tilke.

7. O texto, de 1951 , foi a tese de Gilda de Mello e Sousa.

8."Textiles begin to deteriorate from the moment they are made, and even those chance survivals which make up the story of this book will have been subjected to some environmental damage. Those which were in constant use will almost certainly have suffered de artes decorativas em outros países europeus e, posteriormente, fora da Europa. Em Lyon, por exemplo, a criação do Musée d'Art et d'Industrie, em 1864³ foi o marco inicial da fundação, em 1890, do Musée des Tissus de Lyon, uma das mais importantes coleções de tecidos do mundo 4 .

No Brasil, ainda hoje, pouco sabemos sobre as coleções de tecidos preservadas nos museus: origem, natureza e abrangência ainda aguardam futuras pesquisas. Somente o estado do Rio Grande do Sul, por exemplo, tem revelado coleções e histórias surpreendentes como as da Chácara da Baronesa, em Pelotas (Figura 1), ou a coleção, única, de trajes de banho, no balneário de Torres. Quem sabe em futuro nem tão distante possamos reunir essas coleções virtualmente, a exemplo do que foi feito no Chile (Figura 2) e intensificar, também, a realização de seminários e congressos específicos sobre tecidos no Brasil, também a exemplo do que faz o Chile desde 1986 e o Museu Paulista desde $2006^{5}$.

Diferentes autores concordam ao afirmar que as coleções foram para os museus; também entre nós, um dos principais critérios de avaliação da excelência institucional - seu número, raridade, beleza e características científicas é que qualificavam melhor ou pior aqueles museus que as abrigassem (LOPES, 1997, p. 53; ALVES, 2001 , p. 1301. Entretanto, os trabalhos acadêmicos que se dedicaram ao estudo da história de determinados museus brasileiros, nas últimas décadas, não contemplaram os tecidos; pouco ou quase nada disseram. As menções aos tecidos são eventuais, como por certo foram eventuais os registros dos próprios museus e pesquisadores sobre aqueles objetos. Diferentemente do ocorrido no estrangeiro, onde desde cedo publicações específicas dedicaramse aos tecidos e à indumentária ${ }^{b}$, aqui entre nós nada se comentou de mais consistente. No Museu Paulista, por exemplo, o primeiro texto específico nas publicações institucionais só surgiria em 1951, embora umas poucas inserções sobre o vestuário já aparecessem em textos de alguns etnólogos, publicados na década anterior? Mas como justificar ou compreender tamanho desinteresse? As razões podem ser muitas e bastante diversas.

Jennifer Harris inicia seu livro 5000 years of textiles (1995) lembrandonos de que estudar tecidos depende, antes de mais nada, da sobrevivência, por séculos, daqueles materiais naturalmente propensos à deterioração e criados para serem usados e descartados ${ }^{8}$.

Estudá-los, necessariamente, significa estudar o excepcional e o especial, já que o comum, de uso cotidiano, raramente sobreviveu a seu usuário. No clima brasileiro, os tecidos não encontraram condições naturais favoráveis à sua preservação: J. B. Debret mencionou, em seus relatos, a utilização de baús de zinco, pelas famílias ricas do Rio de Janeiro, para proteger as roupas contra o ataque de insetos"; Alexandre R. Ferreira, já no século XVIII, comentara o mau estado dos tecidos encontrados no Rio Negro e no Grão-Pará, que, segundo ele, precisavam "arejar longe das chuvas" (FERREIRA, 1983, p. 258). 


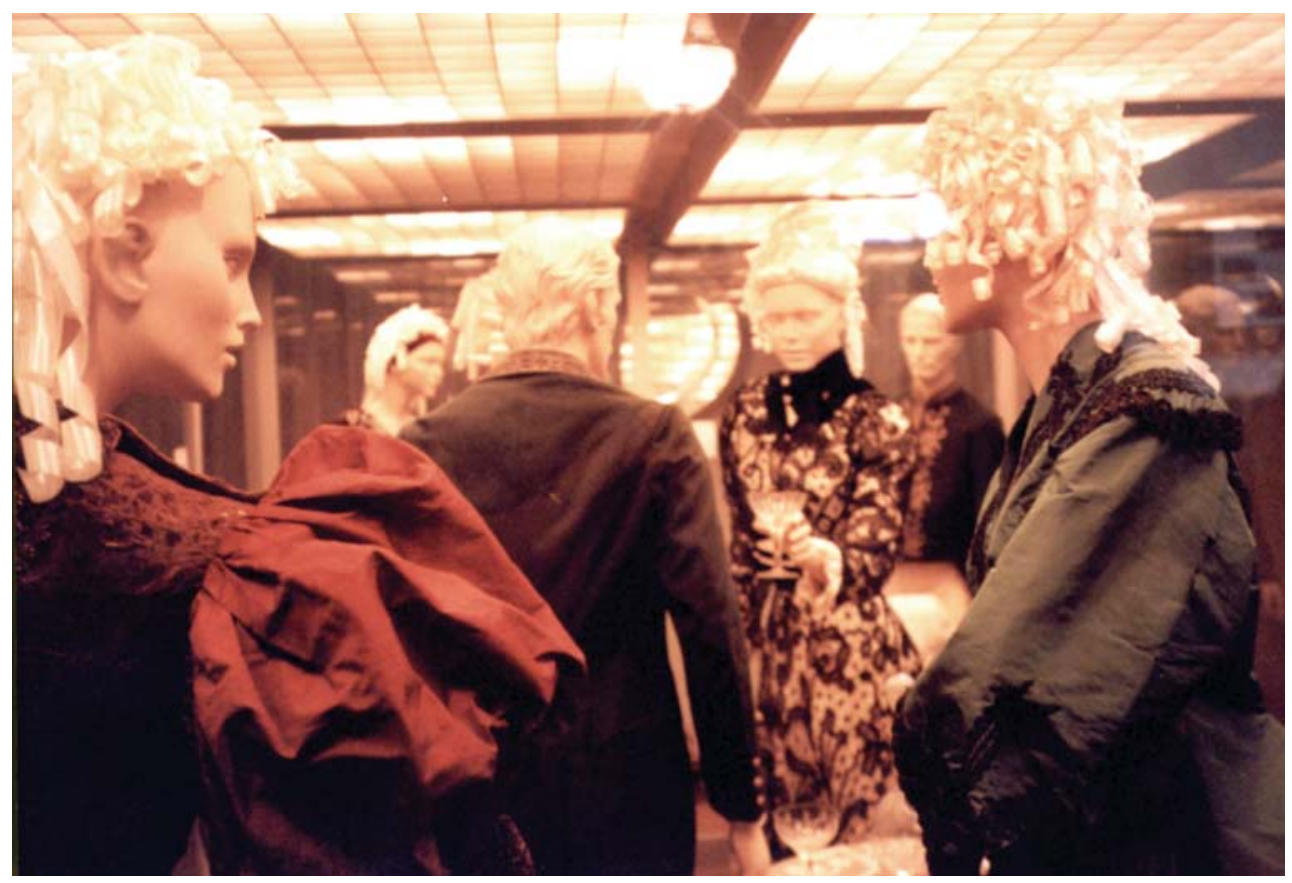

Figura 1 - Detalhe de uma das vitrines até recentemente em exposição no Museu Chácara da Baronesa, em Pelotas, Rio Grande do Sul. A sensação de familiaridade transmitida pela imagem justifica-se pela expografia que copia os padrões visuais das exposições do Costume Institute The Metropolitan Museum, da década de 1960. Fotografia da autora.

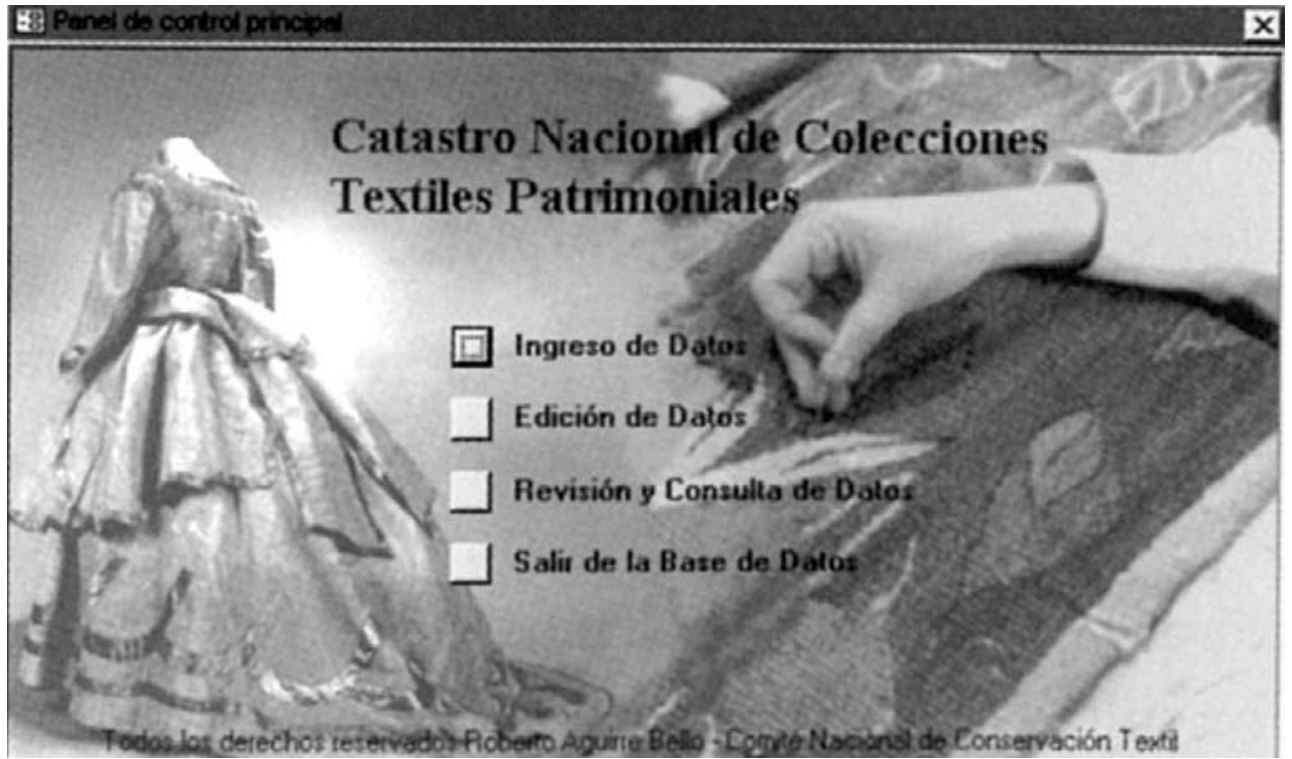

Figura 2 - Tela inicial do cadastro nacional chileno de coleções têxteis. Disponível em: <http://www.cnt.cl/public_catastro.asp>. 
from exposure to light, particularly the ultraviolet rays present both in daylight and in artificial light. The greatest enemy of textiles of all kinds light not only fades the dyes but also embrittles and thus weakens the actual structure of the fibres themselves, hastening disintegration. Climate has a similarly detrimental effect on textiles. Silk will become brittle in dry heat, whilst a humid atmosphere will rot fibres and cause mould to grow and fugitive dyes to 'bleed' into surrounding areas of cloth. When one further considers the damage done to fibers by dust and attacks by clothes' moths and other pests, one begins to wonder that so many textiles have survived at all. In comparison with objects of metal, stone, pottery or glass textiles represent only a small proportion of excavated material. In damp soil the vegetable fibers of which many textiles are made disintegrate entirely, although occasionally the copper salts from oxidised bronze or silver objects pinned to articles of clothing will act to preserve small fragments of cloth from decay Nevertheless, special circumstances in several different parts of the world have meant that some textiles have been preserved, over extraordinarily long periods of time" (HARRIS, 1995, p 8-9)

9. Ver Debret (1978, p. 256).

10. Cf. Conceptual texti les. Material meanings. Sheboyan: John Michael Kohler Arts Center, 1996.
Além disso, os tecidos, certamente por terem sido sempre associados ao corpo e ao gênero femininos, foram muito inferiorizados como objetos de estudo, se comparados a outras tipologias materiais. Herdamos e preservamos por séculos a antiga noção de que um tecido, dada sua proximidade com o corpo e os sentidos, não deveria ser suporte de expressão ${ }^{10}$. Arte decorativa, arte menor, artesanato foram algumas das denominações atribuídas aos tecidos por um mundo masculino, de homens viajantes, homens cientistas, homens de Deus, homens historiadores e homens de museu.

O estudo dos tecidos - na Europa e na América do Norte, que o fazem por séculos -, aconteceu fora da Universidade: tanto o campo da conservação quanto o da pesquisa sobre tecidos desenvolveram-se, historicamente, fora das fronteiras acadêmicas, chegando mesmo, no século XIX, a ser considerado um assunto pouco digno de um homem de letras (TAYLOR, 2002, p. 64). Embora reconhecendo que compreender um tecido ou uma roupa exija conhecimentos específicos, de uma grade bastante ampla de informações, as críticas à produção intelectual específica sempre foram uma constante. Acusado de excessivamente detalhista, o estudo dos tecidos e da indumentária em geral passou a integrar os estudos de cultura material após o lançamento, em 1874, de Notes and Queries pelo Royal Anthropological Institute da Inglaterra (TAYLOR, 2002, p. 1951.

Na língua inglesa, a palavra costume - utilizada desde o século XVIII para denominar o vestir-se - deriva de consuetudo, latim, que pode ser compreendido tanto como costume, no sentido de hábito, quanto no sentido de "Uso" (DRUESEDOW, 1993, p. 4). O tecido aproxima, agasalha, provoca os sentidos e isto, no mundo masculino do século XIX, de homens cientistas (e homens de museu), não deveria ser objeto de atenção. Veremos, mais adiante, que os primeiros objetos têxteis nos museus brasileiros foram quase exclusivamente os masculinos: uniformes militares, bandeiras e outros objetos, sempre associados ao mundo do homem.

Mas há também uma outra questão a ser ponderada, uma especificidade local ou, talvez, de alguns outros países latino-americanos. A tecelagem e a atividade têxtil comerciais, até o século XX, para consumo de outros, foram sempre atividades masculinas em boa parte da Europa colonizadora. Dorothy Burnham comenta que as técnicas de tecelagem e beneficiamento de tecidos foram levadas ao Canadá e aos Estados Unidos por tecelões especializados, todos homens, vindos principalmente da Escócia, Irlanda, Inglaterra e depois da Alemanha (BURNHAM, 1981, p. 171). Geralmente, as mulheres só fiavam e, assim mesmo, apenas para uso doméstico. No Brasil, a tecelagem foi, historicamente, uma atividade de escravos - daí a justificativa econômica do decreto por debaixo dos panos -, e, posteriormente, dos homens libertos e mulheres pobres, ou seja: uma atividade comum, de gente comum e, mesmo, considerada como "inferior". Em São Paulo, no final do século XIX, a profissão de costureira era associada à prostituição urbana, provavelmente 
devido ao fato de as atividades de fiar, tecer e costurar continuarem ligadas à imagem da escravidão doméstica, reforçada, ainda, pelo fato de a maioria das costureiras ter a cor da pele parda (GIBERT, 1993, p. 23-24). Paralelamente, já mais valorizada, surgiu a profissão da modista, que confeccionava e, não, costurava roupas. Costurar não era atividade de gente honesta, e tal distinção social, entre costureiras e modistas, permaneceu até os dias de hoje. Nesse contexto, pouco interessante aos tecidos e às atividades relativas à sua produção, o hiato nos museus começa a parecer razoável; a desatenção para com os tecidos torna-se um tanto mais compreensível.

Optamos, neste texto, por discutir seis características das práticas curatoriais com tecidos, nos museus, no século passado, que, mais do que exemplos isolados, acreditamos, podem ser pensadas como tendências dessas práticas na maioria das instituições museológicas congêneres.

Instabilidade: o passeio institucional dos tecidos nas coleções da USP. Inclusão e exclusão

Uma primeira característica das práticas curatoriais no Brasil a ser comentada seria a instabilidade, um ir e vir das coleções, um movimento que nem sempre fez sentido e poucos rastros deixou. A própria formação das coleções de tecidos, ontem e ainda hoje, tem na instabilidade um valor determinante, constante, já que, no dia seguinte a este, as coleções poderão estar diferentes, acrescidas ou subtraídas de poucas ou muitas unidades.

Os acervos comentados aqui se encontram hoje localizados nos atuais Museu Paulista e Museu de Arqueologia e Etnologia, ambos da Universidade de São Paulo, tendo apresentado três diferentes núcleos de procedência até 1989; embora, cronológica e institucionalmente, vários outros desmembramentos e migrações tenham ocorrido até aquele ano. A Figura $3^{11}$ e a cronologia que a acompanha foram criadas para facilitar a compreensão desses núcleos principais e de seus desmembramentos até o ano de 1989.

$\bigcirc$ primeiro e mais antigo núcleo de tecidos da USP teve origem com a coleção Sertório, em 1890, e a criação do Museu do Estado. Sua história é a história do Museu Paulista até 1989, quando a resolução n. 3560 , da Universidade de São Paulo, reuniu as diferentes coleções de Arqueologia e Etnologia pertencentes a quatro diferentes instituições da universidade - Acervo Plinio Ayrosa (APA); Instituto de Pré-História (IPH); Museu de Arqueologia e Etnologia (MAE); Museu Paulista (MP) -, criando um novo museu, o Museu de Arqueologia e Etnologia, que, embora tenha herdado o nome de uma das extintas instituições, é um novo museu. Até esse momento máximo de instabilidade quando a história da pesquisa científica no Brasil foi desrespeitada, para dizer o mínimo -, tecidos das coleções de história, de arqueologia e de etnologia 


\section{A "migração institucional" dos acervos têxteis}

c. 1890

\section{Coleção Sertório}

Museu do Estado

c. 1895

Museu Paulista

c. 1935

c. 1960

c. 1975

c. 1989

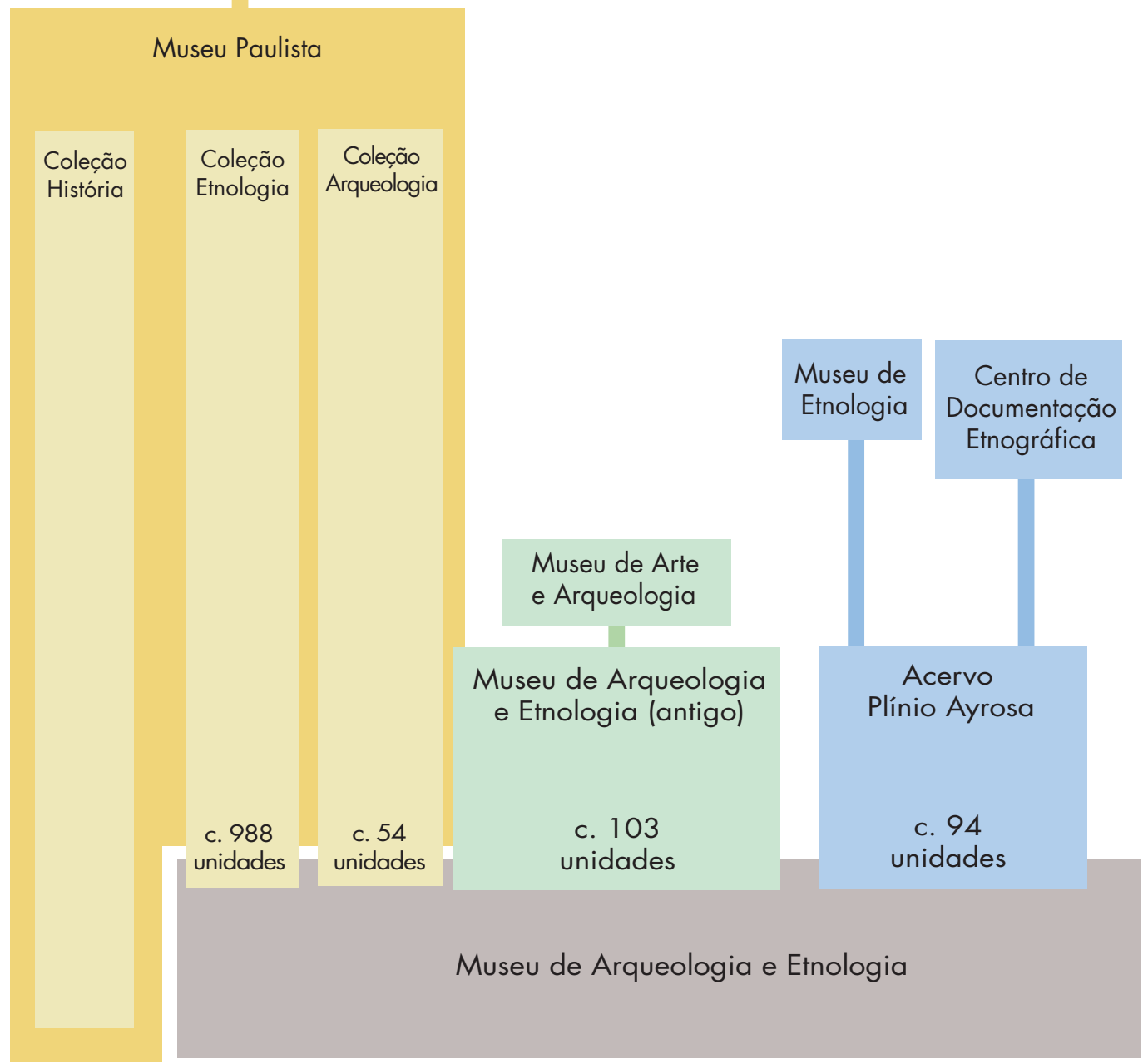

Figura 3 - A migração institucional dos tecidos e cronologia. Desenho de Christine Fidalgo, 2003. 
podiam ser encontrados no acervo do Museu Paulista. A partir de 1989, apenas os tecidos da coleção de história, basicamente, permaneceram no novo Museu Paulista, então transformado em museu de história somente. Os tecidos arqueológicos - aqui entendidos como aqueles procedentes de escavação - e os tecidos "de índio" foram removidos para o novo museu ${ }^{12}$.

Um segundo núcleo de acervo teve origem com a criação do Museu de Arte e Arqueologia (MAA) (Figuras 4 e 5), em 1964, a partir da doação italiana de 536 unidades de acervo. A coleção de tecidos do MAA era formada quase exclusivamente por tecidos e fragmentos andinos (peruanos), doados por Oscar Landmann. A instituição teve vida curta com esse nome, logo se transformando no Museu de Arqueologia e Etnologia, que passou a ter, em sua coleção, além dos tecidos peruanos, um conjunto contemporâneo de tecidos africanos. Esse Museu de Arqueologia e Etnologia foi extinto em 1989.

terceiro núcleo de acervo, afinal, tem seu histórico repleto de hiatos. As poucas informações encontradas, além das que se seguem, foram reproduzidas em outro texto de nossa autoria nesta mesma revista (PAULA, 2005). Consta em texto da antropóloga Dominique Gallois que, em 1935, o Professor Plinio Ayrosa criou o Museu de Etnografia, na então Faculdade de Filosofia, Ciências e Letras;

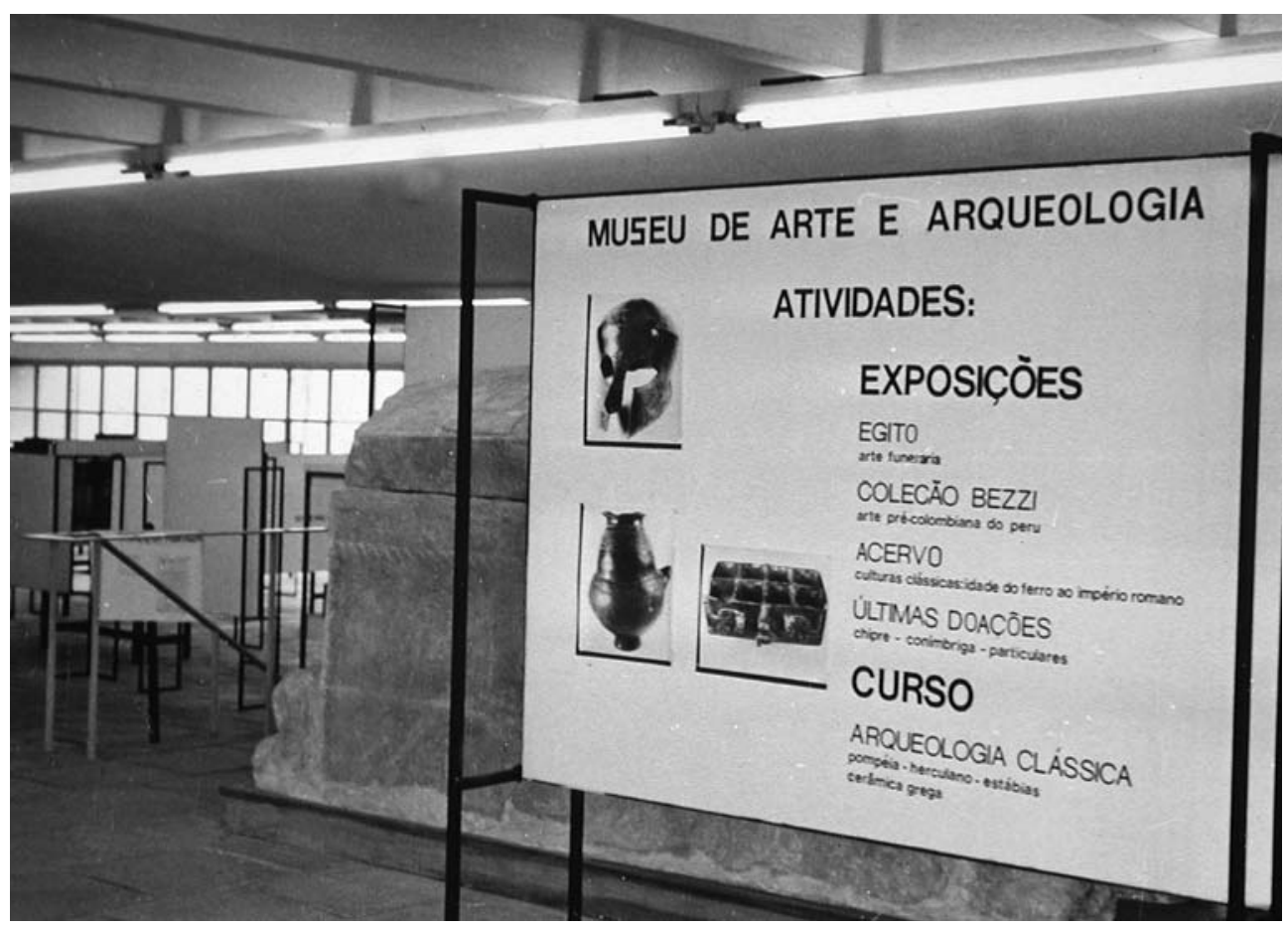

Figura 4 - Painel de entrada do Museu de Arte e Arqueologia (MAA) localizado no andar térreo do prédio dos Departamentos de Geografia e História da FFLCH da USP. Fotografia, s.d. Arquivo do Museu de Arqueologia e Etnologia da Universidade de São Paulo. Reprodução fotográfica de Wagner Souza e Silva.
12. Foram transferidas do Museu Paulista as coleções pertencentes às Seções de Arqueologia, Etnologia e Geografia. 


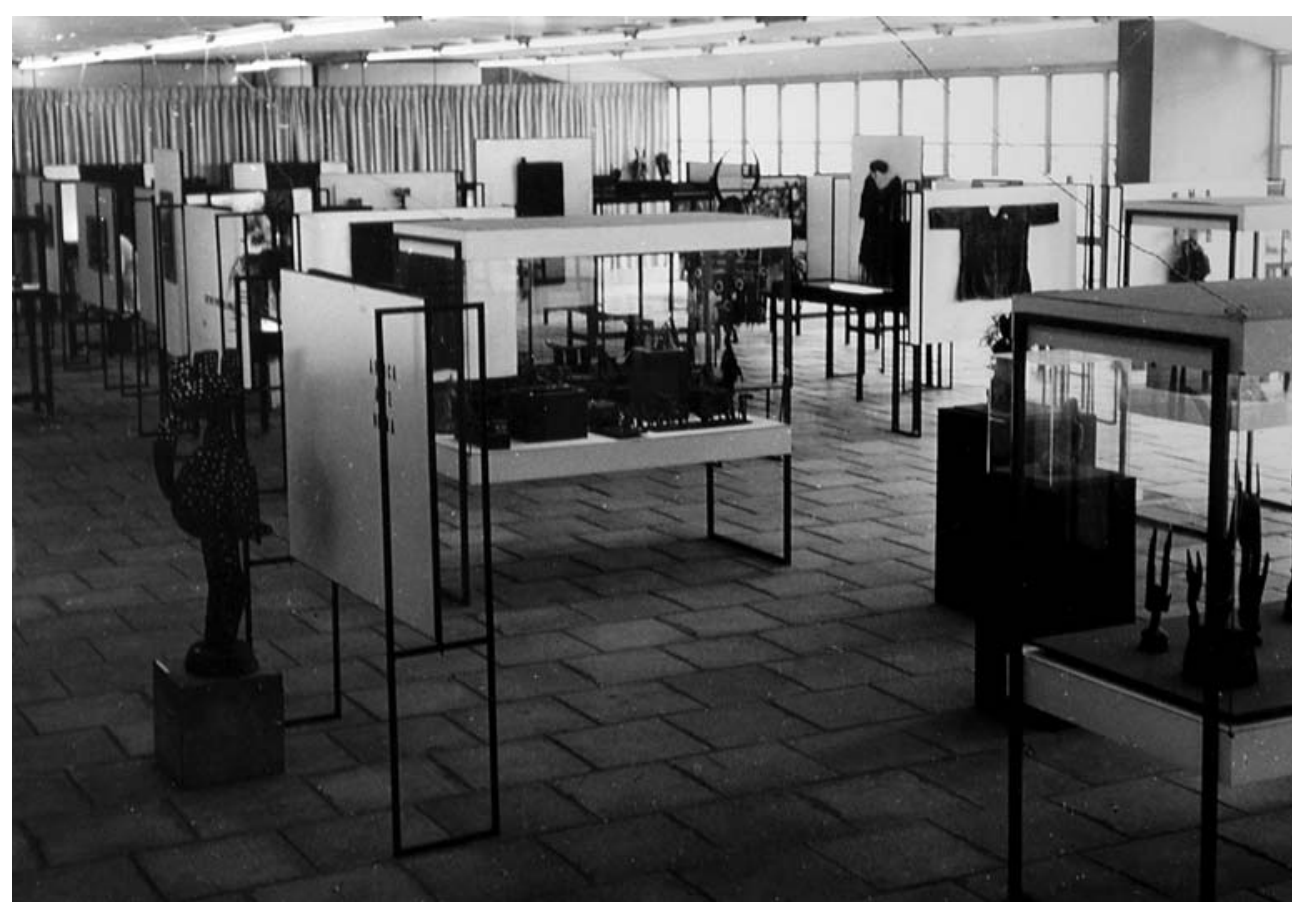

Figura 5 - Vista parcial da exposição do MAA. Fotografia, s.d. Arquivo do Museu de Arqueologia e Etnologia da Universidade de São Paulo. Reprodução fotográfica de Wagner Souza e Silva.

e que, em 1938, o museu teve incorporadas as coleções etnográficas do extinto Centro de Documentação Etnográfica e Social do Instituto de Educação. Nada consta sobre a extinção, fechamento ou mudança do Museu de Etnografia e, alguns parágrafos depois, no mesmo texto, surge o nome Acervo Plinio Ayrosa, relacionado a atividades desenvolvidas no ano de 1975 com aquelas mesmas coleções do Departamento de Antropologia.

Em 1989, esses três núcleos de acervo citados, com exceção dos tecidos históricos do Museu Paulista, foram reunidos e, a despeito de seus diferentes percursos, passaram a integrar o acervo do novo MAE, Museu de Arqueologia e Etnologia.

Thering era um adepto do princípio da separação entre coleções de estudo e as de exibição ao público. Essa idéia, aparentemente óbvia hoje, só começaria a ser introduzida nos museus no final do século passado e se consagraria de fato no início deste século [XX]. Apoiado em Möbius, o curador do Museu de Zoologia de Kiel, na Alemanha, que adotou esse princípio de separação das coleções para a organização desse museu, em 1884, Ihering organizou dessa forma, desde o início, o acervo do Museu Paulista (LOPES, 1997, p. 272).

Uma relação de objetos intitulada Catálogo Antigo, Arquivo Permanente do Museu Paulista, traz identificadas 267 unidades de acervo que 
teriam formado a coleção Sertório, núcleo inicial do acervo do Museu Paulista ${ }^{13}$. Entre cadeirinhas, frascos de vidro, um violão, flagelários jesuítas e outros tantos objetos inusitados, constam aqueles que teriam sido os primeiros objetos em tecido levados para o Ipiranga: uma camisa de Solano Lopez ${ }^{14}$, os paramentos do Padre Feijó, uma toalha, calções militares de camurça, dois leques de baronesas anônimas e dois vestidos azuis. Em relatório de 1907, aparecem mencionadas, pela primeira vez, as bandeiras e, na Revista do Museu Paulista de 1914, menciona-se a doação realizada por Max Uhle em 1912. Esta coleção, em seus 318 objetos, continha mais de 50 tecidos da cultura Inca, dentre fragmentos, tecidos planos e objetos tridimensionais (Figuras 6 e 7). As doações prosseguem com uma camisa "de índio", um guarda-sol, uma rede.

A coleção adquirida para o Museu Paulista no início do século XX por Max Uhle mereceu, em 1977, um catálogo exclusivo, de autoria de Vera Penteado Coelho (COELHO, 1977), com a descrição dos objetos e algumas imagens. Segundo a autora, a coleção foi adquirida de huaqueros, mercadores peruanos de antiguidades, e seria representativa daquelas culturas incas já conhecidas à época da aquisição (1912).

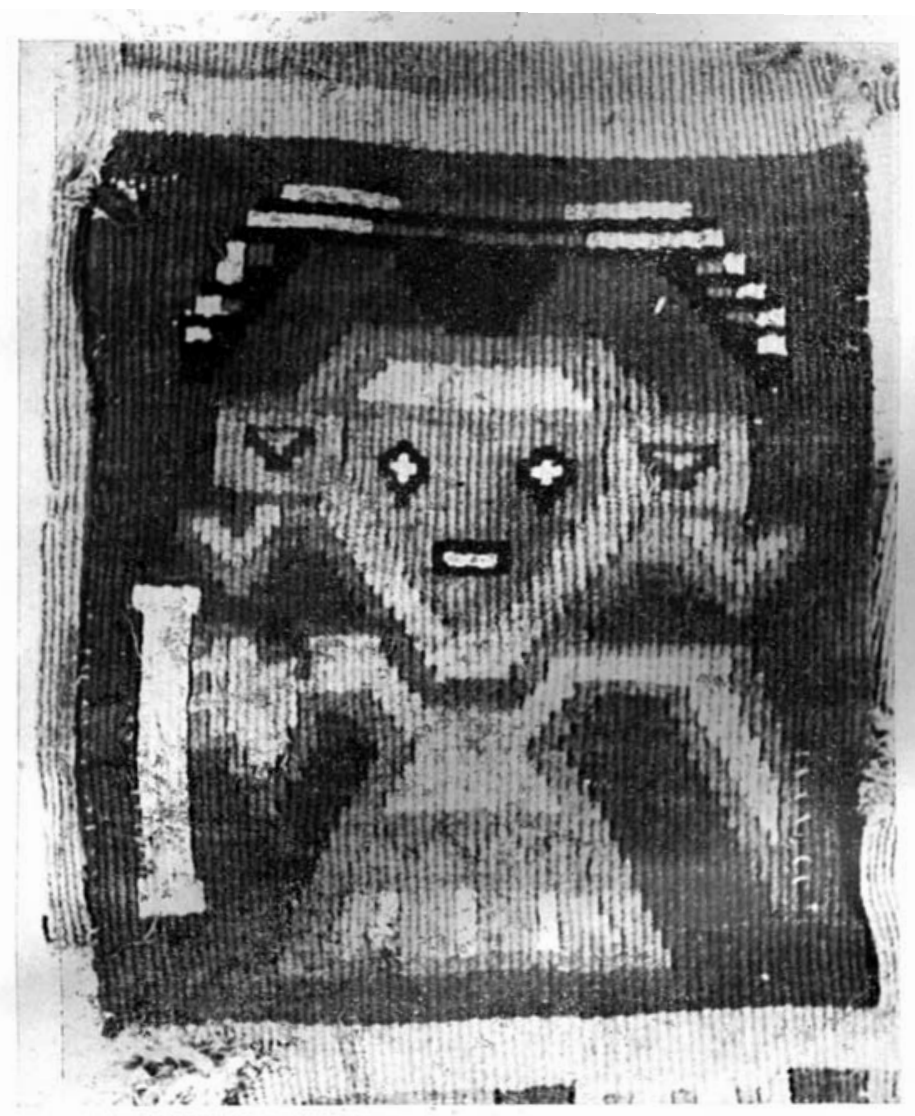

166 Tecido com representações de figuras antrcpomorfas.
13.A cópia da relação, depositada no Serviço de Objetos, integra o Inventário do Arquivo Permanente do Museu Paulista (s. d.).

14 A camisa de Solano Lopez foi um dos estudos de caso de conservação apresentados em nossa dissertação de mestrado.
Figura 6 - Tecido doado por Max Uhle ao Museu Paulista em 1912. Imagem publicada em catálogo exclusivo da coleção em 1977. Acervo transferido do Museu Paulista para o Museu de Arqueologia e Etnologia da USP após 1989. Acervo do Museu Paulista da Universidade de São Paulo. Reproduzido pela Divisão de Acervo e Curadoria. 
Figura 7- Tecido doado por Max Uhle ao Museu Paulista em 1912. Imagem publicada em catálogo exclusivo da coleção em 1977. Acervo transferido do Museu Paulista para o Museu de Arqueologia e Etnologia da USP após 1989. Acervo do Museu Paulista da Universidade de São Paulo. Reproduzido pela Divisão de Acervo e Curadoria.

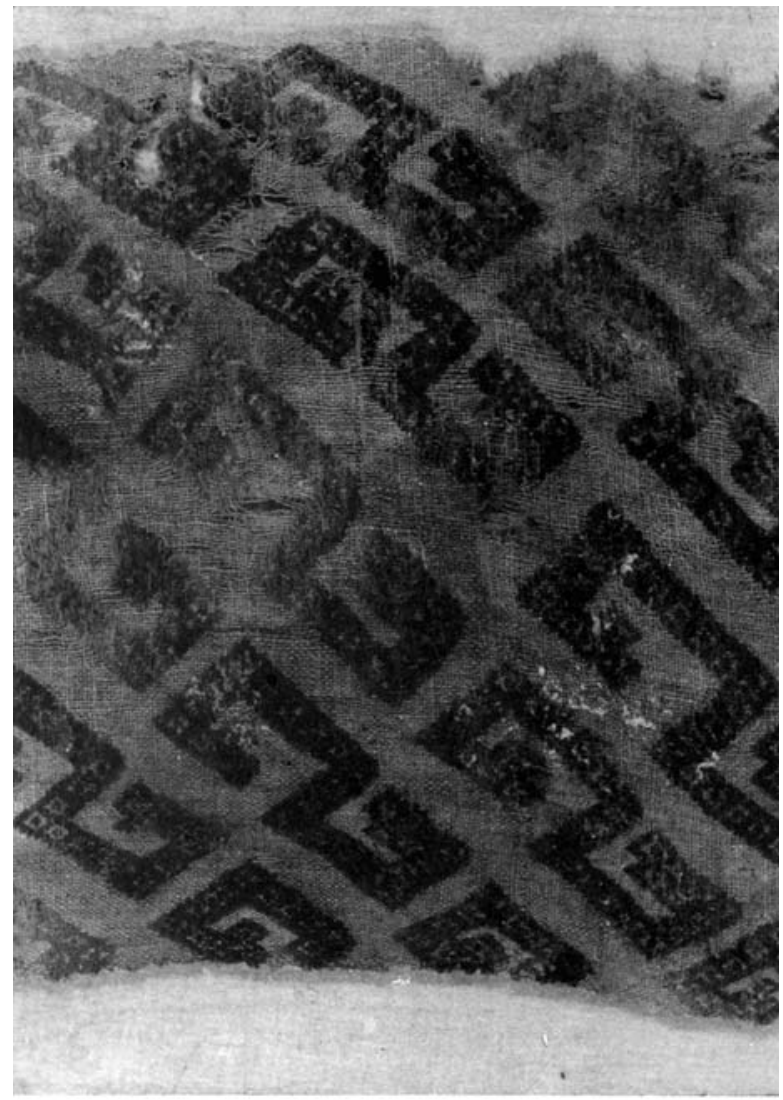

184 Fragmento de tecido com bordados geométricos.

Voltemos à idéia da instabilidade, do ir e vir das coleções, e de uma posição contrária ao desmembramento das coleções do Museu Paulista, por um lado, e fusão de outras coleções, de outro, ocorridos em 1989. Vejamos agora apenas este exemplo da coleção inca: tanto ela quanto o catálogo, bem posterior, pertencem à história do Museu Paulista e das práticas científicas do Museu Paulista, que só foi incorporado à Universidade de São Paulo na década de 1960. Ruptura e perda de sentido. Aqueles objetos incas, quando transferidos, tornaram-se apenas alguns objetos incas, mais objetos incas. Nos primeiros tempos do Ipiranga, aquele acervo inca era muito mais significativo de alguma coisa, muito mais documento de alguma coisa, do que ele consegue ser hoje, esteja onde estiver. Desconhecemos quando e como o Museu Nacional no Rio de Janeiro formou sua coleção de tecidos pré-colombianos, de cerca de 1000 unidades, mas, sem dúvida, os exemplares adquiridos para São Paulo no início do século XX estão relacionados diretamente com a competição científica entre essas duas instituições e ainda uma terceira, o Museu Goeldi. O acervo andino, pré-colombiano, como ainda hoje é classificado, inseriu culturalmente a cidade de São Paulo na "antiguidade" da América do Sul, dando-the uma condição de 
cultura menos jovem, que apenas alguns objetos, como múmias e fragmentos arqueológicos, costumam conferir às instituições ${ }^{15}$. Lá ou cá, enfim, Museu Paulista ou MAE, a coleção Max Uhle foi um dos poucos conjuntos de tecidos estudados até os dias de hoje $e^{16}$.

Pouco se sabe sobre a aquisição dos tecidos índios no Museu Paulista, e parte das informações disponíveis hoje, no MAE, encontram-se relacionadas em nosso doutorado. As notícias nos relatórios anuais das Revistas, desde o final do século XIX, sempre foram genéricas, do tipo "foram registradas e classificadas 488 peças", tendo sido encontradas bem poucas menções exclusivas aos tecidos, geralmente após 1950. A primeira imagem de objetos têxteis, duas bolsas dos índios botocudos do Rio Doce, foi publicada em 1911 (Figura 8).
15.A respeito do valor de antiguidade, ver: Riegl, (1984).

16. Há menções na bibliografia de um estudo sobre os tecidos africanos do MAE, de autoria de Suely Ceravolo, mas ele não foi publicado na $R e$ vista do Museu de Arqueologia e Etnologia.
REVISTA DO MUSEU PAULISTA Vol. VIII.

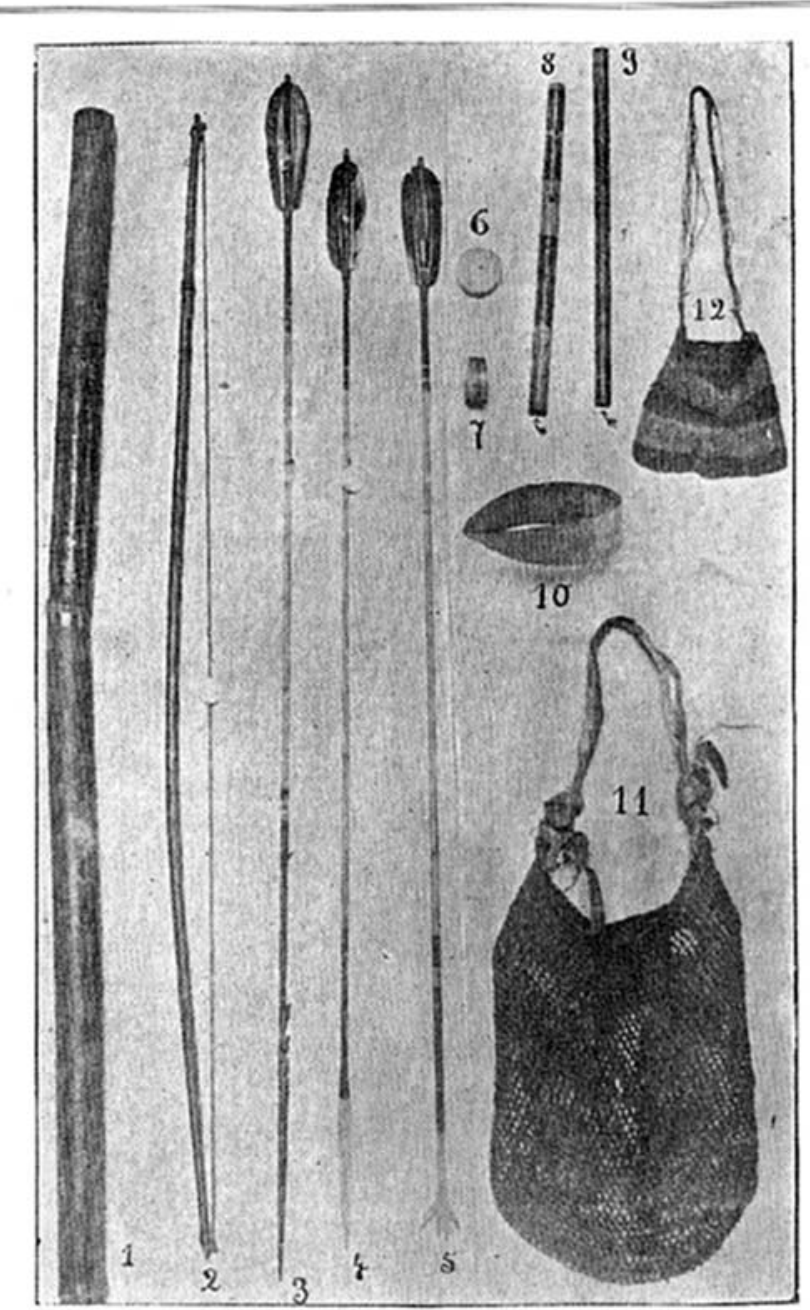

Objectos dos INDIOS BOTOCUDOS DO RIO DOCE

Est. II.
Figura 8 - "Objectos dos Indios Botocudos do Rio Doce". Imagem publicada na Revista do Museu Paulista, v. VIII, 1911 , s/n. Acervo do Museu Paulista da Universidade de São Paulo. Reproduzido pela Divisão de Acervo e Curadoria. 
Da mesma forma que a fauna, a flora e os minerais, o índio e sua cultura foram alvo de estudos científicos realizados no Museu. As tribos sobreviventes, as tribos em extinção e as reminiscências daquelas já desaparecidas eram objetos de interesse, inclusive como documentos dos distintos estágios por que passaria a humanidade rumo à evolução e como possibilidade de encontrar uma resposta para a questão sobre a origem do homem (ALVES, 2001, p. 118).

E assim foi que, por décadas do século XX, expedições científicas partiram do Museu Paulista para todo o Brasil, retornando com lotes de objetos, incluindo tecidos, amostras de fibras e fios, e também dos principais apetrechos (fusos, teares) utilizados nas atividades de fiação e tecelagem. Tecer capacitava, humanizava (Figura 9).

Figura 9 - "Objectos dos Indios Botocudos do Rio Doce". A legenda das imagens diz: "O craneo descripto à pag. 46 é desta mulher, que falleceu dias depois de ter sido photographada". Imagem publicada na Revista do Museu Paulista, v. VIII, 191 1, s/n. Acervo do Museu Paulista da Universidade de São Paulo. Reproduzido pela Divisão de Acervo e Curadoria.

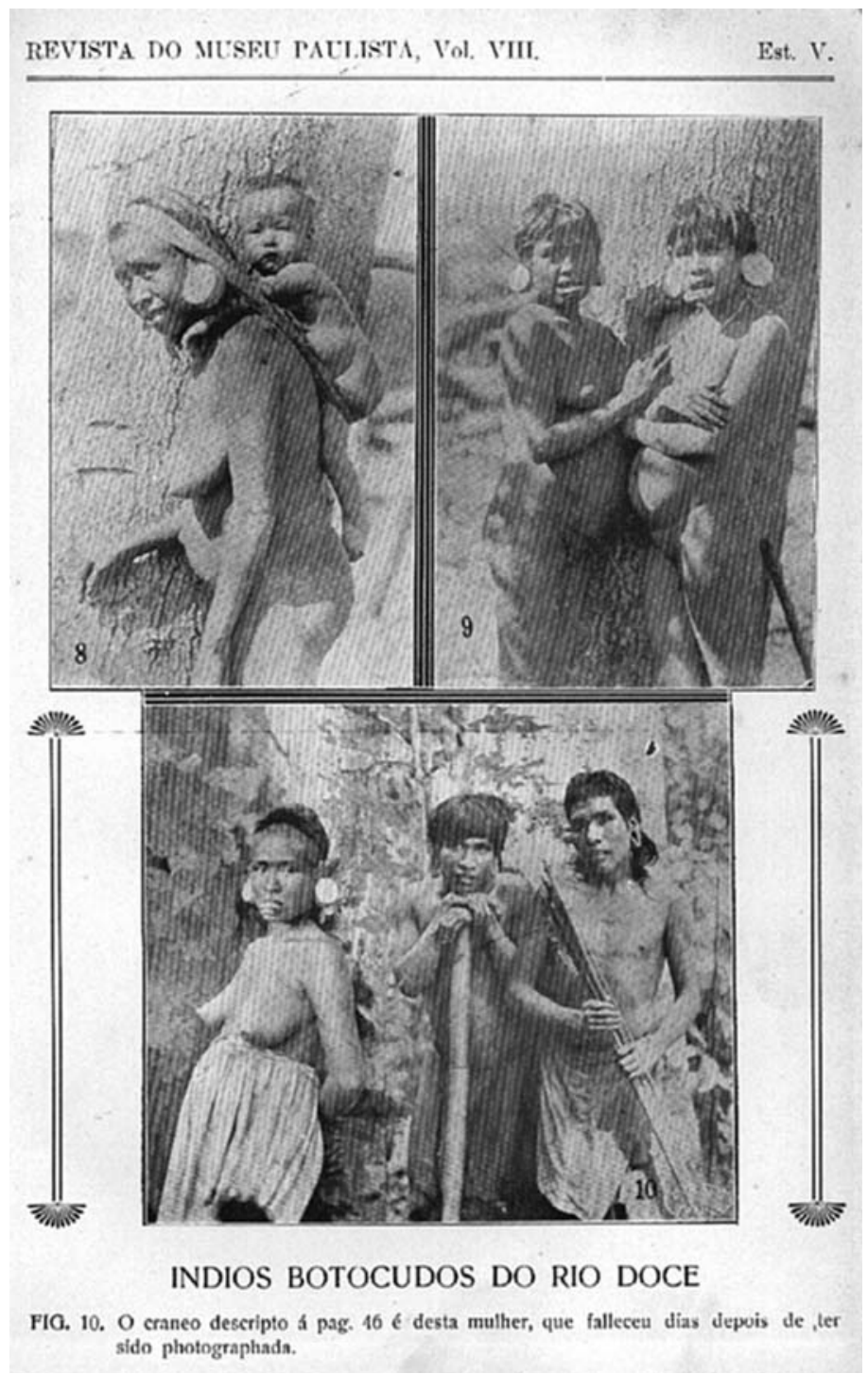


Vários exemplares da Revista do Museu Paulista trazem os relatos das expedições e das coletas de objetos, nem sempre "espontâneas", já que, em diversos momentos, ocorreram encomendas de bens. Os relatos científicos e as imagens, muitas vezes, fazem-nos lembrar das descrições não especializadas de muitos viajantes. É evidente que as mudanças na política indigenista do país e seus reflexos sobre os trabalhos da Seção de Etnologia foram significativas nas diferentes décadas, mas a pouca informação sobre a coleta das coleções, a natureza e a qualidade da atividade científica, permaneceram as mesmas. A instabilidade e a superficialidade, como veremos no próximo tópico, continuaram predominando, a despeito de visões otimistas e demonstrações de exagero, como esta registrada por Herbert Baldus, em 1953:

Posso afirmar que a atual Secção de Etnologia do Museu paulista, no sétimo ano de sua existência, já não faz má figura ao lado dos museus etnológicos do velho e do Novo Mundo. É verdade que, em tamanho, continua sendo um anão entre gigantes. Mas, já se está aproximando do fim para o qual a orientei desde sua criação: tornar-se, dentro do organismo do Museu Paulista, um museu sui-generis, o "Museu do Índio Brasileiro". Ainda que estejamos longe de possuir o número de peças do Museu de Gotemburgo ou do nosso Museu nacional, andamos em bom caminho para satisfazer, como poucos museus do mundo, as exigências científicas modernas. Nossas expedições foram organizadas sempre no sentido de colher, não tanto peças espetaculares, mas todo e qualquer objeto que possa contribuir para ilustrar a cultura material de uma tribo em sua totalidade (BALDUS, 1953, p. 423).

A comparação com as instituições estrangeiras foi sempre uma constante, mas só naquilo que interessava: qualidade e quantidade do que se colecionava e exibia. Documentação, conservação e pesquisa raramente foram comparadas.

Paralelamente, e sempre concorrente, crescia a coleção histórica do museu, obrigando lhering a fazer concessões e conviver, inclusive, com o quadro de Pedro Américo (LOPES, 1997, p. 270). De tudo um pouco foi sendo coletado, em velocidade e ritmo sempre instáveis. Por muitas décadas predominaram os acervos masculinos, os tecidos masculinos, indumentária ou não, como os uniformes, as bandeiras e demais objetos relacionados com as atividades nas guerras, batalhas e revoluções, independentemente de sua procedência. Contase em relatos, documentos e confidências de antigos pesquisadores, que a prática de substituir unidades de acervo em más condições era comum, e que algumas roupas, sujas de sangue, terra ou com mau cheiro, por exemplo, teriam sido jogadas fora, sem que disso tenha sido feito registro: mais do que uma prática localizada, esta foi uma história comum a muitos museus brasileiros no século passado.

Com o esquartejamento do Museu Paulista em 1989 e a criação do novo MAE, permaneceram no lpiranga apenas aqueles têxteis registrados na Seção de História. Aquilo que era coisa de índio foi se juntar a seus semelhantes em outro Museu, a despeito de serem documentos também históricos: afinal índio não é História, índio é índio. Índio é Etnografia. A partir de então, as coleções com objetos têxteis no Museu Paulista cresceram substancialmente. No ano de 
17. Este percentual foi apresentado no balanço realizado na época pelo Serviço de Objetos e refere-se, apenas, ao acervo de indumentária e objetos pessoais. Outras coleções com tecidos, como as de brinquedos, por exemplo, não foram estimadas.
2000, estimou-se um crescimento como superior a 170\% ${ }^{17}$. Boa parte dessa coleção - enriquecida e agora predominantemente feminina -, já se encontra no banco de dados informatizado, o que permitirá, em breve, uma quantificação exata de todos os tecidos do acervo.

Poucas são as informações, além daquelas anexadas, sobre a coleta de todos os outros tecidos das outras instituições extintas em 1989, e que hoje são acervo do MAE. A exceção a ser destacada é a coleção de tecidos africanos que, afirma-se, foi adquirida por Mariano Carneiro da Cunha na década de 1980:

A compra foi efetuada em Dakar (Senegal) uma espécie de entreposto de arte africana, e na República Popular do Benin (antigo Daomé). [...] Essa diversidade geográfica se expressa numa grande variedade de produtos (jóias, máscaras, estatuetas, tecidos) e técnicas (metalurgia, escultura, tecelagem, trançado) (SALUM; CERAVOLO, 1993).

Em 1993, o atual MAE teve seu conjunto de tecidos ampliado, com a doação de quinze fragmentos coptas e catorze objetos peruanos, basicamente fragmentos, a coleção Gilbert C. Y. Asmar.

Superficialidade: o hiato na documentação

Em Bahia Negra vimos Chamacocos pela primeira vez.[...] Agora estes 'civilisados' ganhavam a vida a cortar madeira, suas mulheres se tinham tornado lavadeiras e aguadeiras ou faziam 'trabalhos de índios': adornos de plumas, esteiras tecidas, bolsas e semelhantes 'raridades' para museus e gente basofia [bazófia]. [...] Encontrámos um Chamacoco, moço bonito e intelligente, que, fazia alguns annos, viajara com um austríaco pela Europa. Mostrou-nos uma revista com o seu retrato e um album de photographias de Vienna. Mas além d'isso nada de europeo the ficara. Tinha regredido aos costumes dos seus irmãos, andava meio ou inteiramente nú, recordava-se apenas ainda dos paizes afastados [...] Um dos membros da expedição não conseguiu obter uma india a troco das nossas mais preciosas joias falsas. Mas quando deu ao pai vinte cartuchos de carabina, este trouxe-the à meia-noite, a filha à nossa tenda (BALDUS, 1927).

Nenhuma outra atividade curatorial no século passado, principalmente até a década de 1980, poderia ser tão bem caracterizada como superficial quanto a documentação das coleções. A desinformação foi e ainda é uma tendência no Brasil e uma característica comum nos diferentes núcleos de acervo em discussão neste texto. A informação, se existente, quase sempre é incerta, repleta de lacunas e contradições. Faltaram tanto conhecimento específico quanto método nos trabalhos curatoriais (Figura 10).

Documentar tecidos, em teoria, implica bem mais do que apenas identificar a matéria-prima utilizada em sua produção. É preciso responder lou tentar responder) algumas questões básicas: 


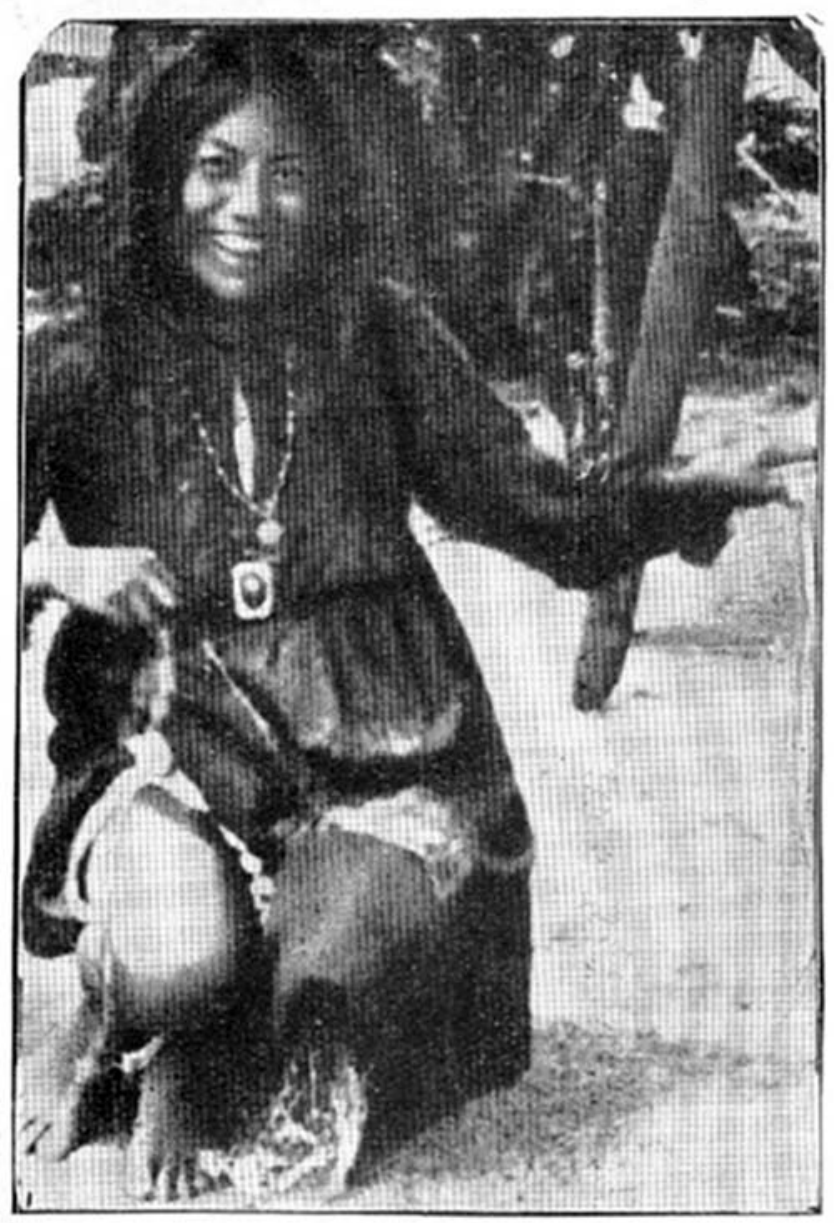

Moça Chamacoco - (typica tchimitchana) - preparando fibras de caraguatá para tecer
Figura 10 - Imagem publicada na Revista do Museu Paulista, tomo XV, 1927, s/n. A legenda da imagem diz "Moça Chamacoco - (typica tchimitchana) - preparando fibras de caraguatá para tecer". Acervo do Museu Paulista da Universidade de São Paulo. Reproduzido pela Divisão de Acervo e Curadoria.

1. De que material foram feitos esses fios?

2. Quem os fiou e como?

3. Que tecido é esse?

4. Quem o teceu e como?

5. Que materiais e técnicas foram usados para colori-lo?

6. Como ele foi colorido e por quem?

7. Quando e onde ocorreu tudo isso?

Nas publicações institucionais, apenas um estudo além do catálogo da coleção Max Uhle pôde ser encontrado. Sylvio Fróes de Abreu, estudando 
18. Revista do Museu Paulista,Tomo XVI. os índios crenaques, em 1926, ficou intrigado com a forma de tramar daquelas mulheres; segundo ele, o trabalho que faziam lembrava o crochê e o tricô e, as rendas, lembravam a renda Renascença. $\bigcirc$ artigo é ilustrado, demonstrando o argumento do autor (Figura 11 ) $^{18}$

Além deste exemplo solitário temos pouco mais a citar. A publicação sobre a coleção Max Uhle merece mais uma vez ser comentada. Todos os tecidos foram documentados em suas dimensões, cores, procedências, matérias-primas e, acima de tudo, em suas decorações. O objeto cuja descrição é a mais extensa é o de número 156 do catálogo e diz o seguinte:

Faixa de tecido de algodão, trabalho inconcluso; os fios da urdidura (em número de 32) encontram-se torcidos entre si e estão enrolados em um pequeno novelo; a decoração consta
Figura 11 - As imagens da figura são respectivamente: detalhe do tecido do bornal dos Botocudos (em cores); bornal de pano de algodão e bolas de barro (à esquerda); bornal de fibra de barriguda tingido com amarelo de urucús e roxo de anjút (à direita); renda renascença. Ponto de filó simples (abaixo). Revista do Museu Paulista, tomo XVI, s/n. Acervo do Museu Paulista da Universidade de São Paulo. Reproduzido pela Divisão de Acervo e Curadoria.

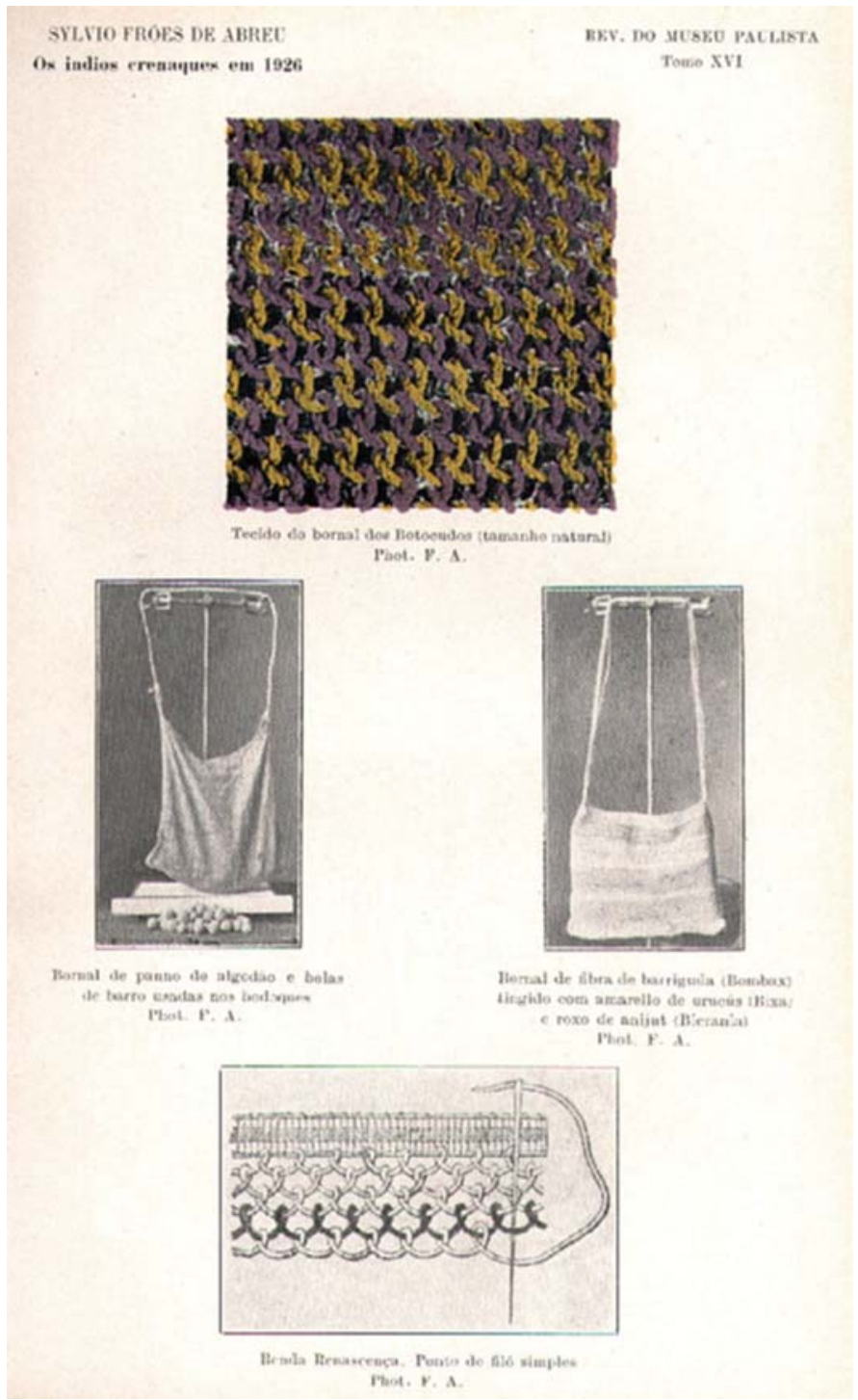

Anais do Museu Paulista.v. 14.n.2. jul.-dez. 2006. 
de várias séries de figuras: arabescos formando semi-círculos, serpentes e cabeças zoomorfas isoladas. Tanto os fios da trama como os da urdidura são brancos e em alguns trechos eles foram deixados visíveis, servindo de fundo para o campo decorativo; em outros casos foram recobertos de fios vermelhos que passaram a servir de fundo para as figuras. A decoração é toda obtida pelo bordado que, em alguns casos, especialmente quando se trata das figuras entrelaçadas, procuram imitar os contornos típicos das figuras produzidas no tear. Em alguns trechos podem-se notar pequenas falhas na execução do trabalho, o que leva a pensar que o artesão que o executou era ainda um tanto inexperiente: uma das cabeças zoomorfas (bordada em sentido perpendicular ao dos fios da urdidura) comprimiu estes fios produzindo um estreitamento da faixa; além disso, só uma das cabeças zoomorfas lelas são em número de três) é que pode ser vista igualmente pelo avesso e pelo direito, fato que ocorre sempre nos bordados mais aprimorados. Esta peça é extremamente interessante, pois permite ver claramente a maneira como trabalhavam os antigos artesãos, desenhando a figura à medida em que o próprio tecido ia sendo elaborado (COELHO, 1977, p. 75-76).

A ênfase da descrição acima está quase toda nas imagens do tecido e não no tecido, no material, embora haja uma tentativa de discutir a técnica de tecelagem. Incompleta ou não, a publicação registra uma tentativa, um caminho de trabalho que, infelizmente, não foi sequer copiado.

As fichas que documentaram a coleção Plinio Ayrosa também apresentam alguns exemplos. Um deles, curioso, documenta uma rede, de número 1 167, e diz:

Rede tecida seguindo a técnica entretecida (twined) recebendo os cordéis da trama e da urdidura, quando da fiação, torção feita em Z por dois elementos. Quando da sua confecção são necessários cerca de 2 mil e 500 metros de fio.

A quantificação mencionada é curiosa, assim como a descrição confusa. Seria mais simples se houvesse registro da bibliografia, do manual de técnicas e/ou terminologia adotados. Desde 1980, a terminologia têxtil encontra-se satisfatoriamente estudada e descrita na publicação Warp and Weft, de Dorothy Burnham, obra de referência em qualquer estudo sobre tecidos (BURNHAM, 1980). A publicação, que traz a nomenclatura em sete idiomas, deveria ser do conhecimento daqueles que se propõem a estudar tecidos, principalmente na universidade. A superficialidade foi padrão, tendência inclusive nos museus universitários.

catálogo Museu Paulista, de $1984^{19}$ - que integrou uma série de volumes editados pelo Banco Safra sobre vários museus brasileiros -, traz algumas unidades de acervo em tecido, com comentários e referências que merecem alguma atenção. A publicação apresenta conjuntos de objetos fotografados em cores, destacados e comentados; e, ao final, outros tantos com pequenas fotos em branco e preto e algumas informações técnicas. As Figuras 12, 13 e 14 pertencem ao primeiro grupo destacado. Já as das Figuras 15 e 16 pertencem ao segundo grupo.

As imagens deixam clara a superficialidade das curadorias e das atividades ditas científicas até bem pouco tempo, especialmente quando consideramos que a maioria desses objetos foi coletada há pelo menos cinqüenta anos. Meio século é muito tempo. A única conclusão possível faz-se evidente: a 
Figura 12 - $\bigcirc$ texto refere-se apenas ao tear, o tecido em construção sequer é mencionado. Note-se no texto a frase inicial: "Qualquer que seja o tipo de tear empregado ele é sempre manual". $\bigcirc$ que esta frase pretendeu dizer? Acervo transferido do Museu Paulista para o Museu de Arqueologia e Etnologia da USP após 1989. Fotografia de Romulo Fialdini. O MUSEU Paulista (1984, p. 107). Acervo do Museu Paulista da Universidade de São Paulo.

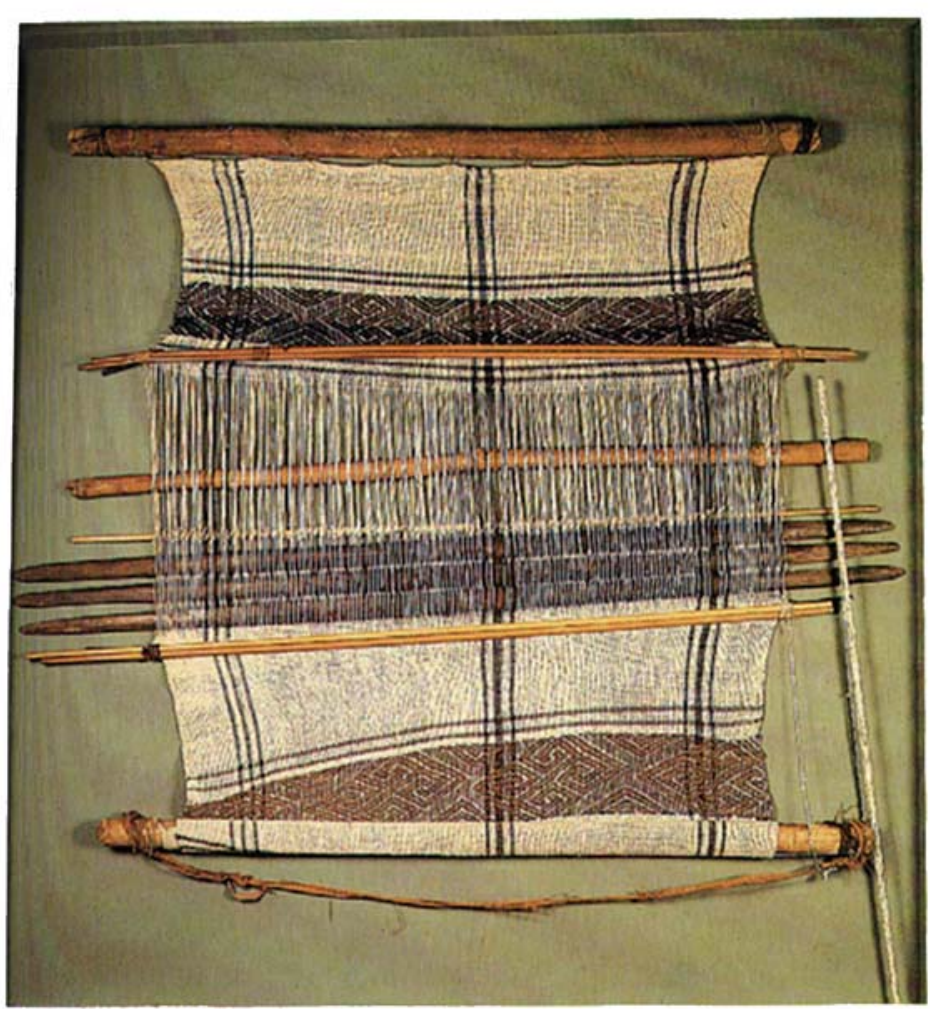

TEAR DE CNTIRA COM INSTRUMENTAI

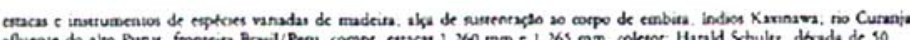

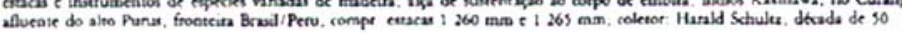

Qualquer que seja o ripo de teat empregado, eles sto semper manuais. Os mais comuns constituem-se de dois paus fincados no chio, ao tedot dos quais um fio e enfolado: outro fio passa transversalmente pot esta urdidura, formando a trama.

urdidura, formando a trama.

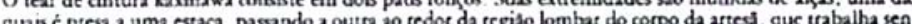
tada no cháo sobre uma esteira. A urdiduta é foxada as paus por meio de lagadas espacadas de cordés

superficialidade não era um problema, era uma decorrência inevitável do colecionismo, do exagero, uma propriedade dos museus. A história das práticas curatoriais no Brasil e nos museus universitários ainda está por ser escrita, mas uma leitura das narrativas e da produção científica publicadas nas revistas institucionais apenas evidenciam um movimento irregular dos trabalhos em atividades pautadas na idéia de preservação, de permanência.

As legendas e os textos que acompanhavam as imagens mostradas nas páginas anteriores muito pouco diziam; e o que diziam, nem sempre fazia sentido ou acrescentava algo àquilo que os olhos podiam informar. Os objetos relacionados ao final do catálogo citado, por sua vez, mostraram informações sem qualquer padrão: alguns tiveram as cores mencionadas; outros os materiais, ou as técnicas, ou os nomes de quem os usou. No caso dos têxteis peruanos, o 


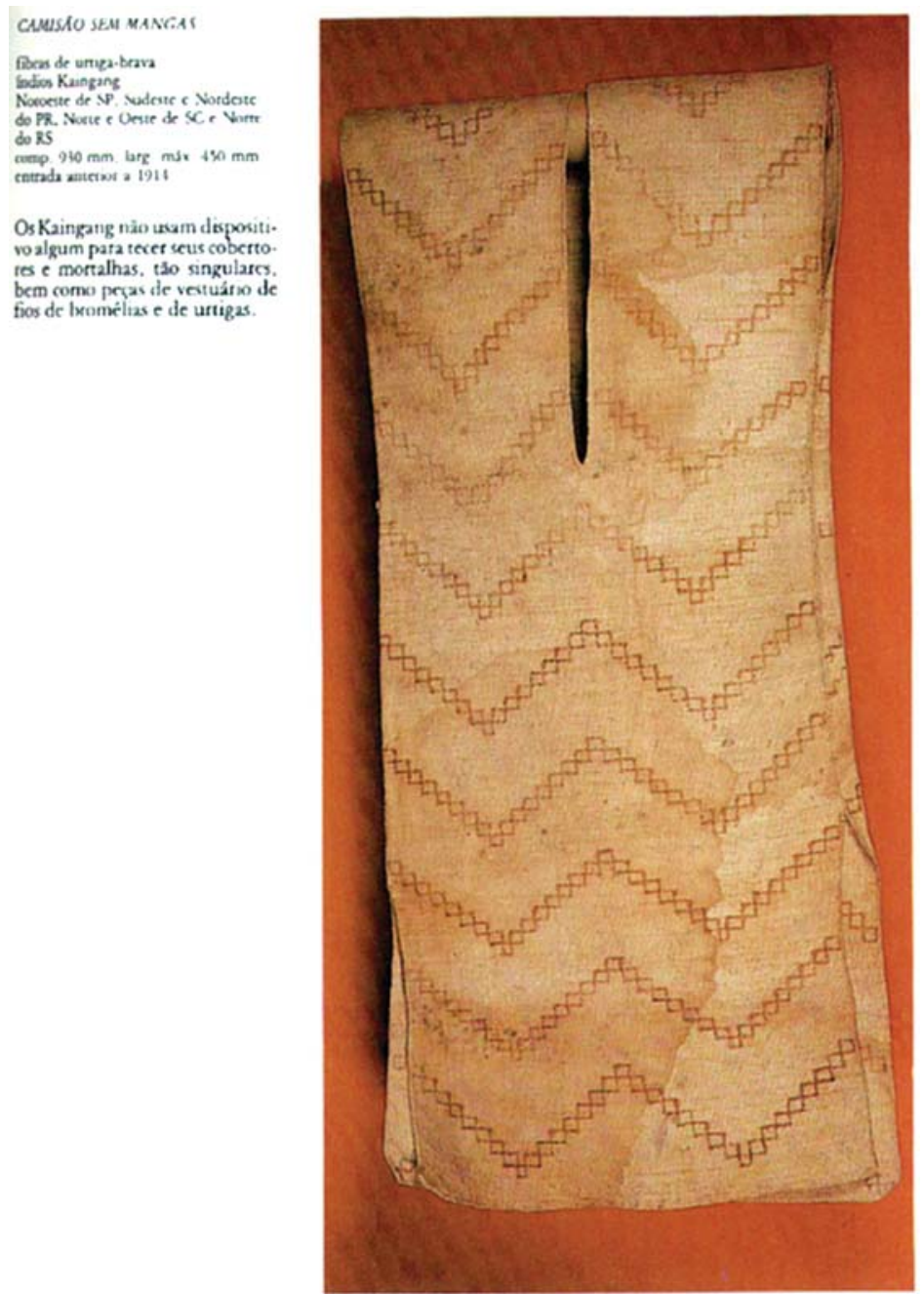

Figura 13 - $\bigcirc$ texto explicativo sobre este Camisão é igualmente confuso "Os Kaingang não usam dispositivo algum para tecer..." Qual a informação? Os kaingang utilizam-se apenas dos dedos? Como? Acervo transferido do Museu Paulista para o Museu de Arqueologia e Etnologia da USP após 1989. Fotografia de Romulo Fialdini. O MUSEU Paulista (1984, p. 11 1). Acervo do Museu Paulista da Universidade de São Paulo.

catálogo foi ainda mais estranho. A Bolsa Decorada nº 6084 já constava na publicação institucional sobre a coleção Max Uhle, quase dez anos antes, e com informações mais detalhadas do que as apresentadas; a Atiradeira de Lã $n^{\circ} 6098$ e o Fragmento nㅇ 6080, idem ${ }^{20}$. Dez anos depois, as informações publicadas pioraram tanto em qualidade quanto em critério; o esforço da publicação anterior em acertar foi totalmente ignorado.

Com o vai e vem de acervos, após 1989, entre os dois museus Museu Paulista e Museu de Arqueologia e Etnologia -, então outros museus conceberam novos projetos documentais que vêm, em velocidades diferentes, organizando as coleções segundo as tendências atuais da documentação museológica ${ }^{21}$. Os tecidos, entretanto, ainda aguardam por uma documentação apropriada, especializada.
20. No catálogo citado, ver páginas 73,78 e 79 respectivamente.

21. Entre outros, ver o texto de Botallo, (1998). Sobre o sistema documental do Museu Paulista, cf. Barbuy; Lima; Carvalho, (2002, p.13-29). 


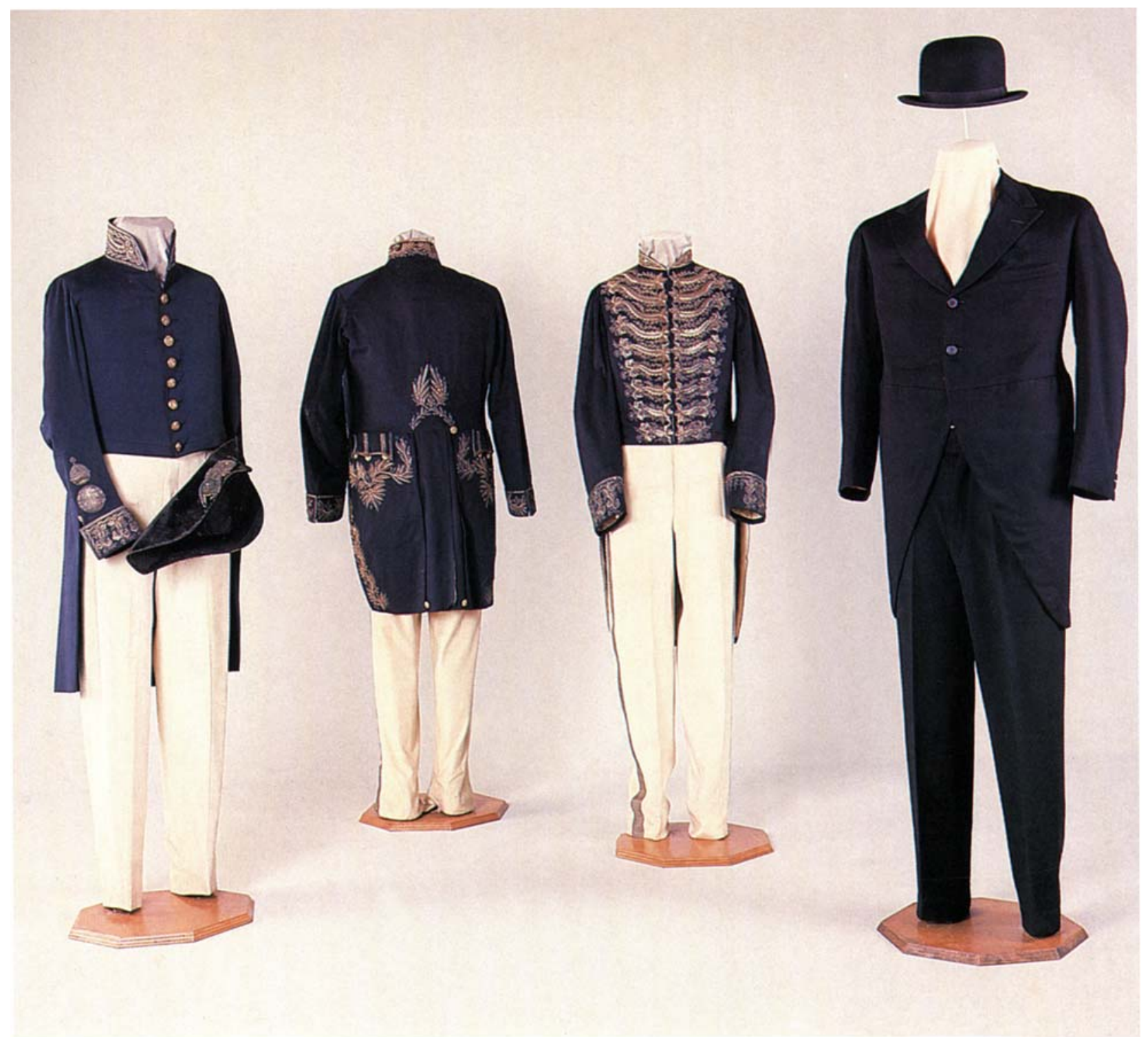

UNIFORMES DE MINISTRO DE ESTADO E DE SENADOR DO IMPÉRIO E TRAJE CIVIL DE GALA - SÉCULO XIX

O traje civil de gala, composto de casaca e chapéu-coco, pertenceu ao Alferes Manuel J. de Lima.

Figura 14 - Uniformes da Guarda Nacional e de autoridades durante o Império. Os textos são econômicos. Acervo Museu Paulista da Universidade de São Paulo. Fotografia de Romulo Fialdini. O MUSEU Paulista (1984, p. 217). Acervo do Museu Paulista da Universidade de São Paulo. 


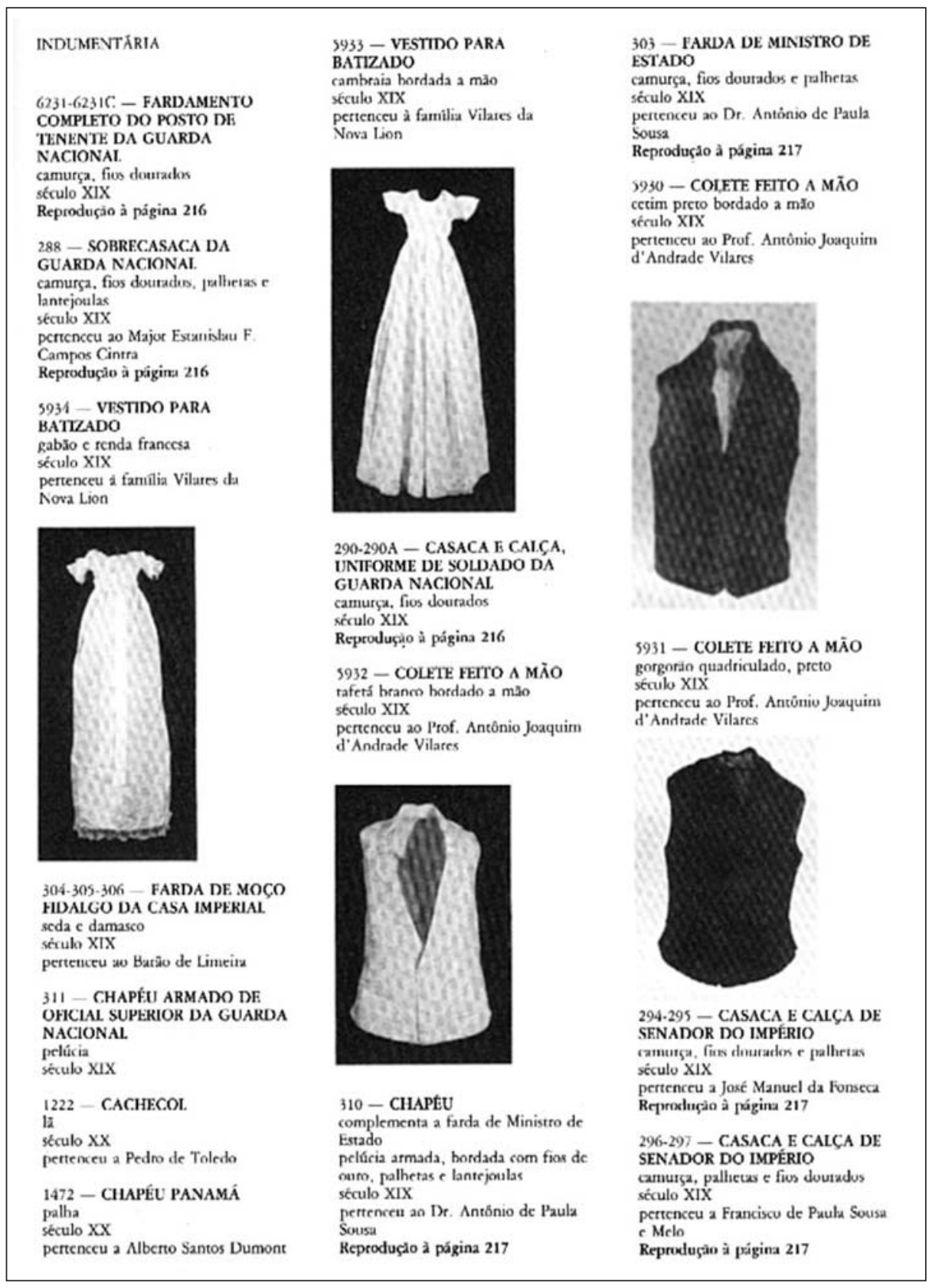

Figura 15 - As diferentes roupas contêm informações de diferentes naturezas. Algumas mencionam o material do tecido, outras a cor, outras a técnica. Não há padrão. Acervo Museu Paulista da Universidade de São Paulo. Fotografias de Romulo Fialdini. O MUSEU Paulista (1984, p. 299). Acervo do Museu Paulista da Universidade de São Paulo. 


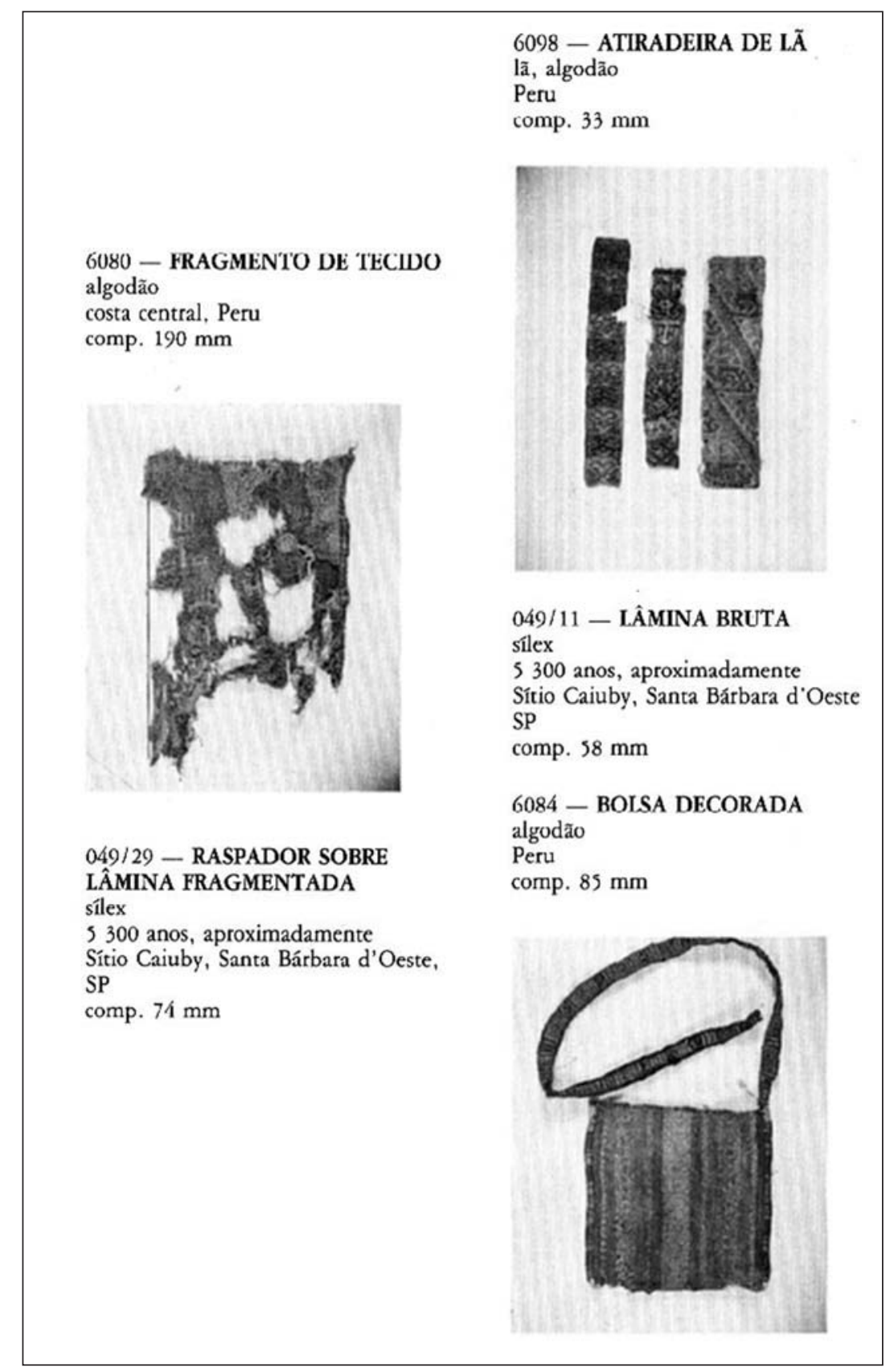

Figura 16 - As informações são vazias embora o museu já tivesse publicado, quase uma década antes, um catálogo bastante completo sobre tecidos e objetos peruanos (Coleção Max Uhle). Acervo transferido do Museu Paulista para o Museu de Arqueologia e Etnologia da USP após 1989. Fotografias de Romulo Fialdini. O MUSEU Paulista (1984, p. 269). Acervo do Museu Paulista da Universidade de São Paulo. 
Impermanência: longe da conservação e dos olhos. Substituição e descarte.

Era Bezzi um excelente architecto, cheio de elevada inspiração esthetica; [...] construiu seu palacio como bem entendeu [...] abriu, no segundo andar do edificio, duas lindas galerias, na fachada anterior [...] mas, para conseguir estes effeitos architectonicos, precisou sacrificar a habitabilidade do edificio, pois teve de passar para a face sul todas as salas e comodos fechados. Ora, sendo o Ypiranga açoutado por frigidissimos ventos encanados no Alto da Serra do Mar, a insolação destes commodos posteriores veio a se tornar nulla. Não tardou a Comissão a verificar quanto seria insalubre alojar creanças em local tão humido, durante os mezes de inverno paulistano, por vezes, sobremodo aspero (TAUNAY, 1927).

Até meados do século passado, com certeza, as considerações de Alexandre Ferreira na Viagem Filosófica (FERREIRA, 1983), sobre a necessidade de "arejar os tecidos", poderiam ser estendidas a todo o Brasil e a todos os museus e seus acervos - mesmo além das zonas equatoriais -, quando, então, algumas práticas de conservação começaram a ser adotadas no Brasil.

A frase insetos e bolor por toda parte dominou os registros dos diretores e pesquisadores do Museu Paulista desde sua criação. $\bigcirc$ edifício, então bem mais aberto do que é hoje, em meio ao descampado (Figura 17), atormentou os cientistas e o público visitante que, muitas vezes, era inclusive deixado na chuva, sem piedade, para que não arrastasse para dentro do museu o barro que se amontoava nos arredores.

As queixas - sobre as más condições de conservação daquilo que se encontrava exposto - já estavam registradas nos relatórios de Hermann von Ihering para os anos de 1901-1902, e foram repetidas e repetidas, muitas e muitas vezes, nas várias décadas:

Em consequencia do bolôr, produzido pela humidade do clima, tornou-se bastante dificil a conservação das collecções e impossivel a dos rotulos explicativos, que necessitavam de uma substituição, quasi que completa (VON IHERING, 1904).

Outros temas freqüentes das queixas foram a poeira excessiva e o desbotamento causado pela ação da luz:

Ao assumir a Diretoria do Museu fiquei mal impressionado com o estado de pouco aceio [asseio] em que se mantinham não só muitos dos móveis das salas de exposição com o avultado material que parecia desde longos annos não haver soffrido uma reforma por assim dizer indispensável a muitos exemplares. A primeira vista ressaltava o descaso com que desde longos annos viviam as collecções destinadas ao publico [...] Admirei-me contudo de que se não houvesse tomado providencias contra o desbotamento provocado pela ação directa da luz sobre o material [...] ordenei que os vidros dos armários fossem pintados de preto e que se adaptassem cortina às estantes vedando a luz (VON IHERING, 1917).

Mas, como já afirmamos, essa não foi uma história exclusiva do Ipiranga. Sabe-se que muitos museus no Brasil descartaram unidades de acervo em más condições de conservação, queimaram molduras infestadas por cupins 
22. Ver Brooks (2000, p. 21).

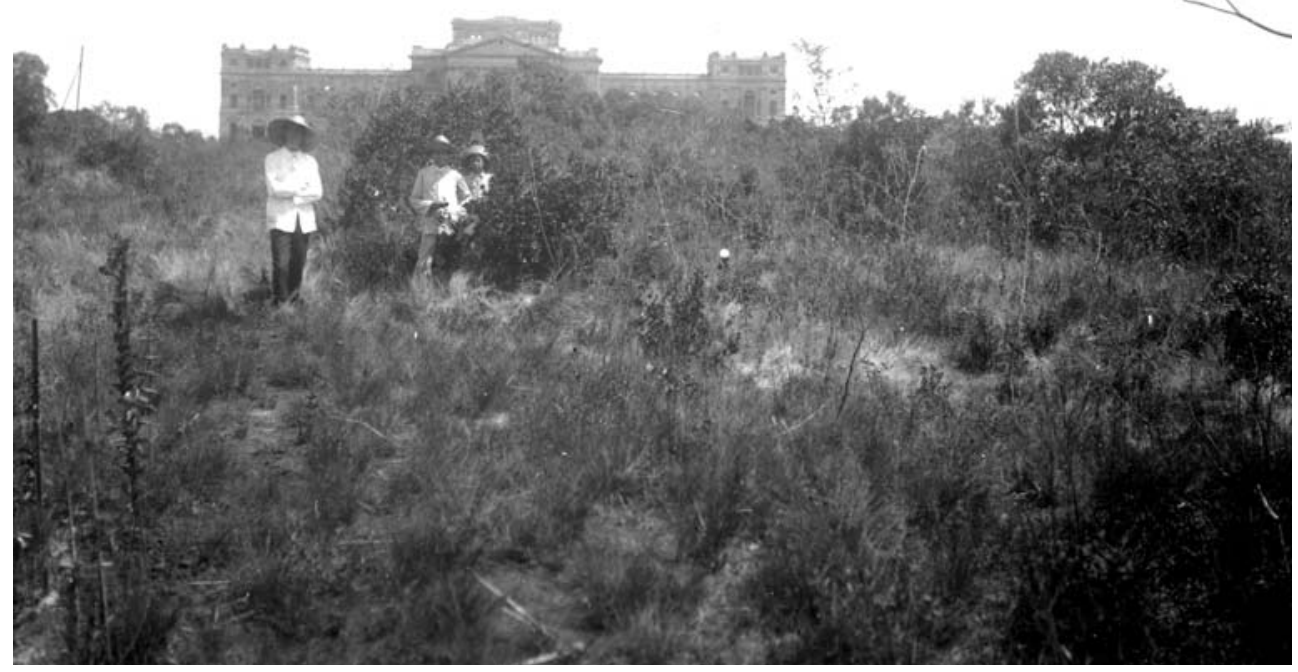

Figura 17 - A imagem dá uma idéia dos arredores do Museu Paulista no final do século XIX. As reclamações contra o barro e o mau tratamento dispensado aos visitantes nos dias de chuva foram registradas pela imprensa e justificadas pelos diretores do museu que culpavam as autoridades pela más condições barrentas do entorno. O MUSEU Paulista (1984, p. 8). Acervo do Museu Paulista da Universidade de São Paulo. Reprodução fotográfica de Romulo Fialdini.

e, mesmo, serraram grandes objetos para conseguir acondicioná-los em locais nem tão grandes assim. E aqui, novamente, a exemplo do que ocorrera com a documentação, mencione-se, não se copiaram os procedimentos adotados nos museus estrangeiros: o ir e vir de diretores e pesquisadores à Europa não se fez refletir na conservação das coleções.

Na Inglaterra, por exemplo, já se discutiam - em 1857 - os possíveis efeitos daninhos da polvição, do aquecimento e da iluminação a gás sobre as pinturas do South Kensington Museum e da National Gallery:

To test the effects arising from atmosphere, as well as those from the use of gas lighting collections of pictures for evening exhibitions, a series of coloured tests have been prepared [...] These tests all prepared under exactly similar conditions, have been hung not only in the galleries at South Kensington, but also at the British Museum, the National Gallery, and in various other localities and in varied atmospheres, both in London and in clear atmosphere remote from town ${ }^{22}$.

Particularmente, sobre o melhor ou pior estado de conservação dos tecidos, quase nada se registrou. Os tecidos são materiais especialmente frágeis 
e suscetíveis à deterioração. As coleções que permaneceram no Museu Paulista após 1989 apresentavam (e ainda apresentam) todo tipo de problema estrrutural: da decomposição natural daqueles materiais mais sensíveis, como a seda, por exemplo, a cortes, manchas d'água, de gordura e "ferrugem", perdas causadas por insetos etc. As imagens a seguir - parte de um conjunto preparado por nós em 1992 e levado à Inglaterra -, são exemplos dos diferentes tipos de dano registrados nos tecidos após décadas de exposição, manuseio e acondicionamento inadequados. As Figuras 18 e 19 são exemplos de tecidos atacados por insetos; os das Figuras 20 e 21 apresentam manchas (deslocamento das cores) causadas por água, com os tecidos dobrados, armazenados. Já os problemas apresentados pelos objetos das Figuras 22, 23, 24 e 25 foram causados (ou agravados) pelo longo período em exposição. Finalmente, as bandeiras (Figuras 26, 27 e 28) mostram os danos causados, em prazo longo, pela armazenagem inadequada. Estes exemplos são freqüentemente encontrados em várias outras unidades do acervo que permaneceu no lpiranga, sendo comum

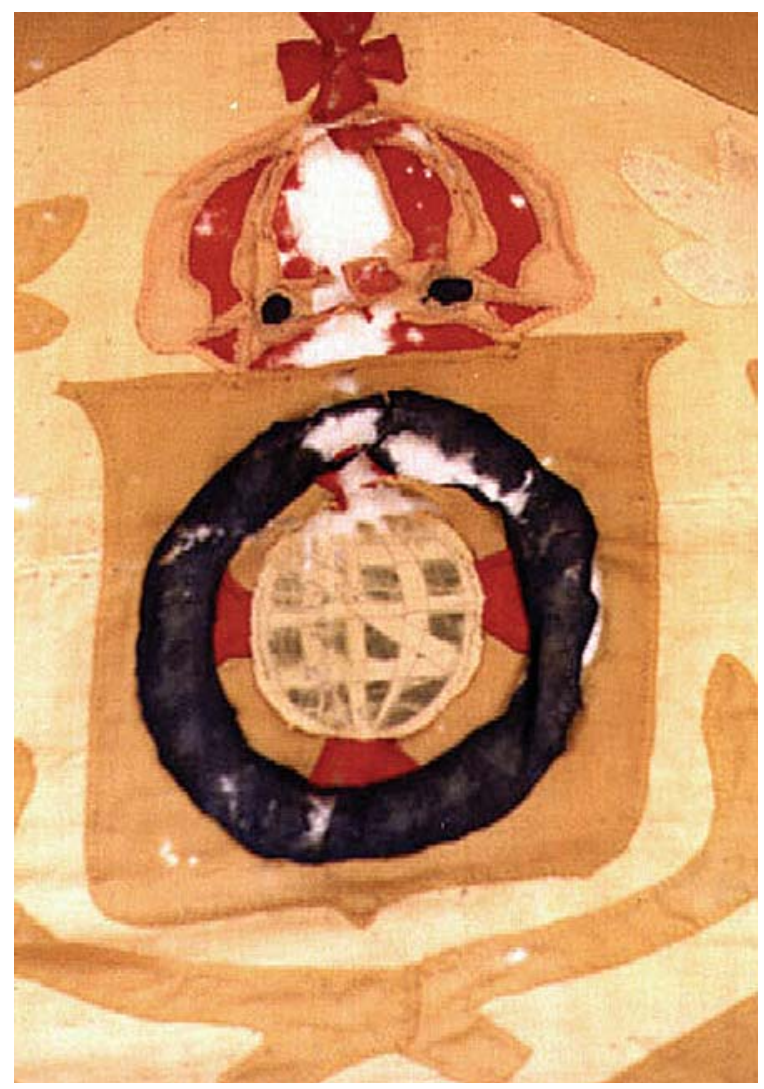

Figura 18 - Detalhe da área central da bandeira imperial do Brasil (RG 976). Acervo do Museu Paulista da Universidade de São Paulo. Fotografia da autora. 


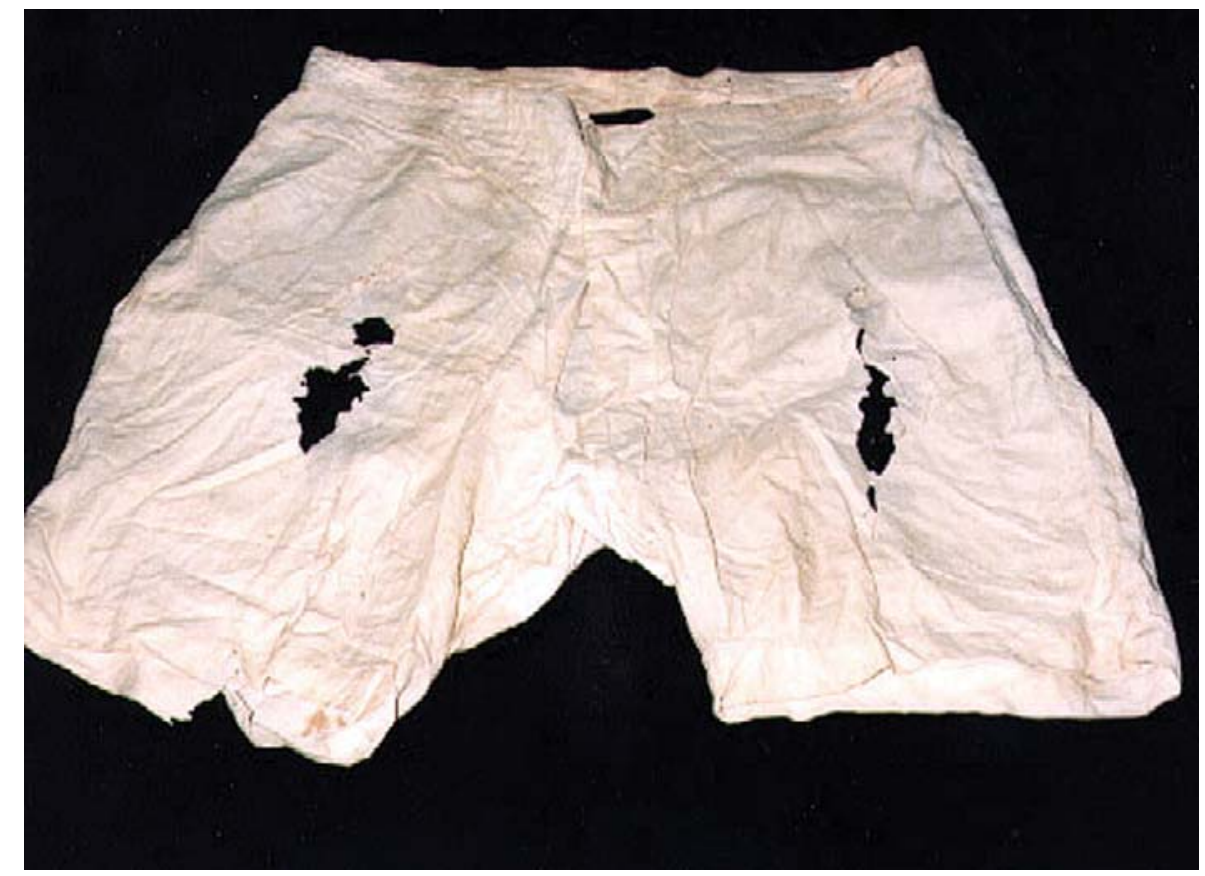

Figura 19 - Ceroula masculina RG 6886. Note-se que a roupa foi atacada por insetos quando se encontrava dobrada. Acervo do Museu Paulista da Universidade de São Paulo. Fotografia da autora.

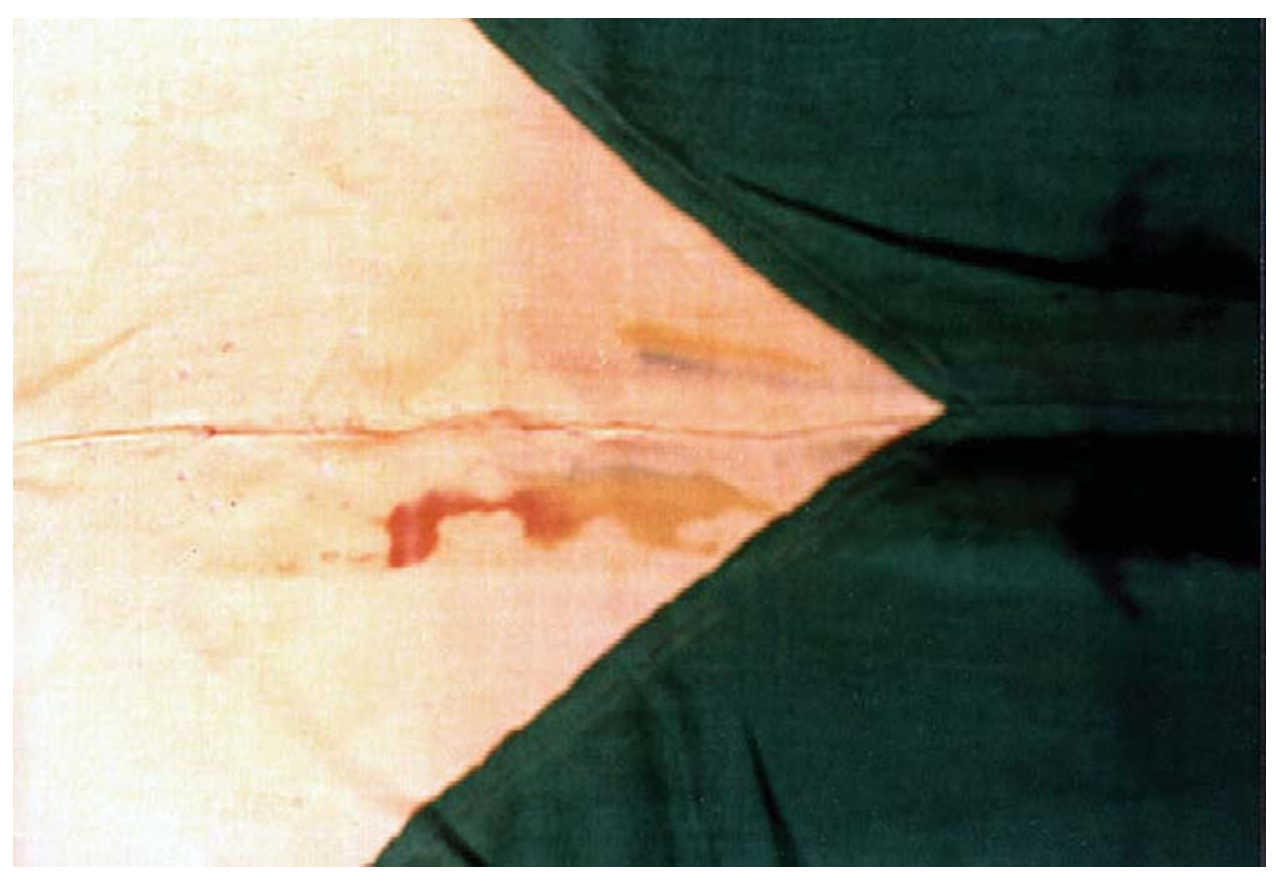

Figura 20 - Detalhe da metade direita de bandeira imperial do Brasil (RG 6398). Note-se a migração das cores causada pela água no local de armazenagem. Acervo do Museu Paulista da Universidade de São Paulo. Fotografia da autora. 


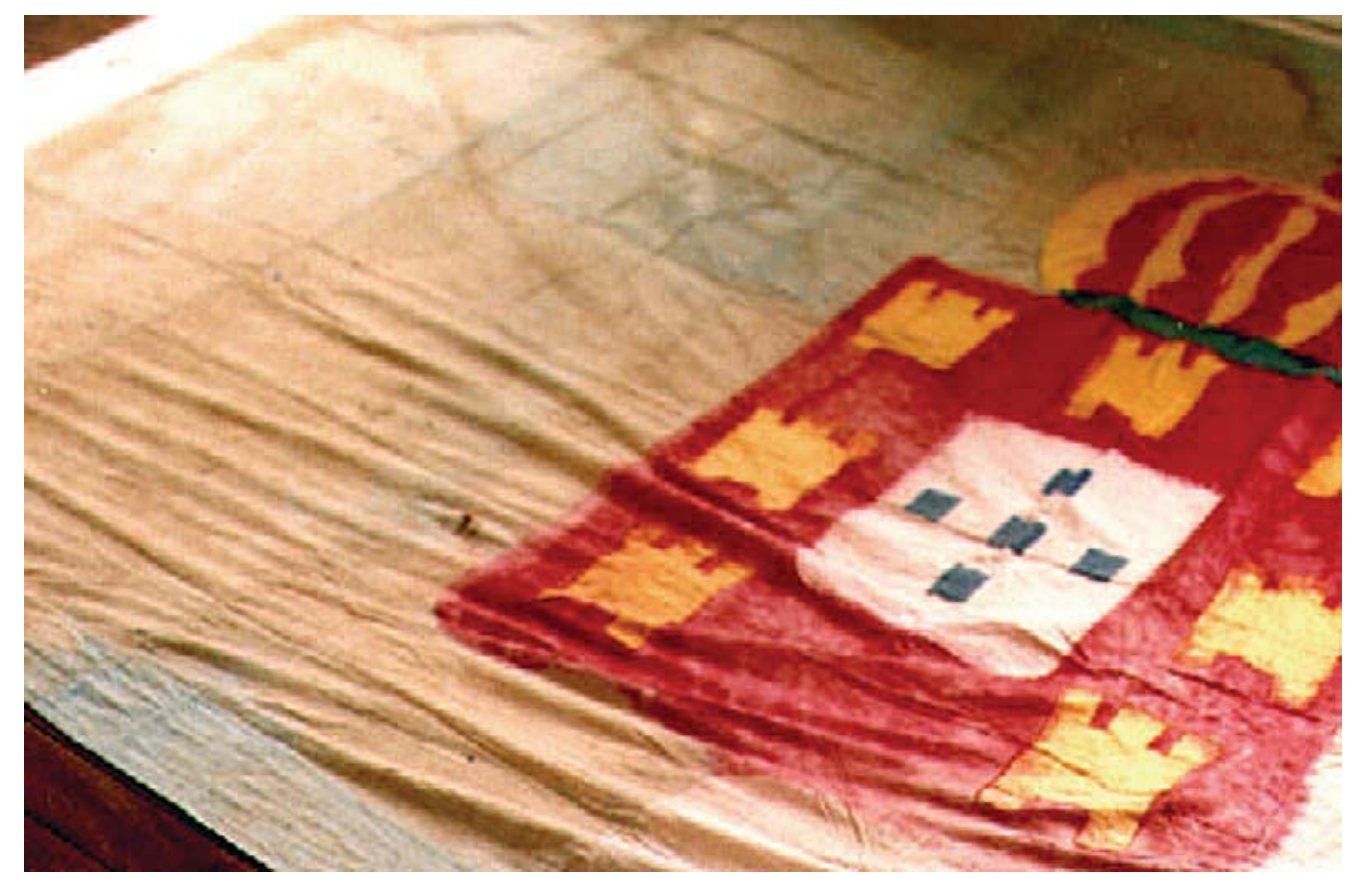

Figura 21 - Detalhe da parte central e esquerda da bandeira portuguesa do Regime Constitucional (RG 5047). Note-se a migração das cores causada pela água no local de armazenagem. Acervo do Museu Paulista da Universidade de São Paulo. Fotografia da autora.

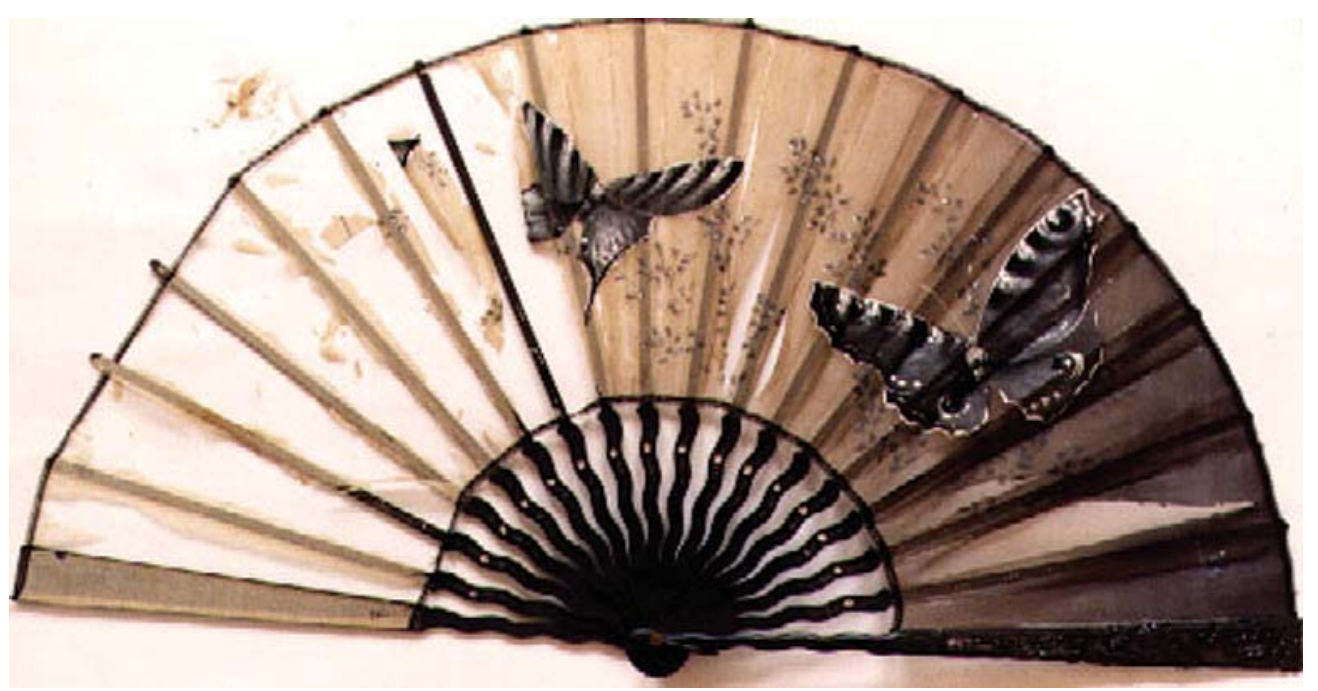

Figura 22 - Leque em seda com bordados e pintura, varetas de madeira (RG 71). Expor os leques em posição excessivamente aberta e por longos períodos foi uma prática generalizada aos museus. Uma vez deteriorados eram removidos de exposição e substituídos por outros. Acervo do Museu Paulista da Universidade de São Paulo. Fotografia da autora. 


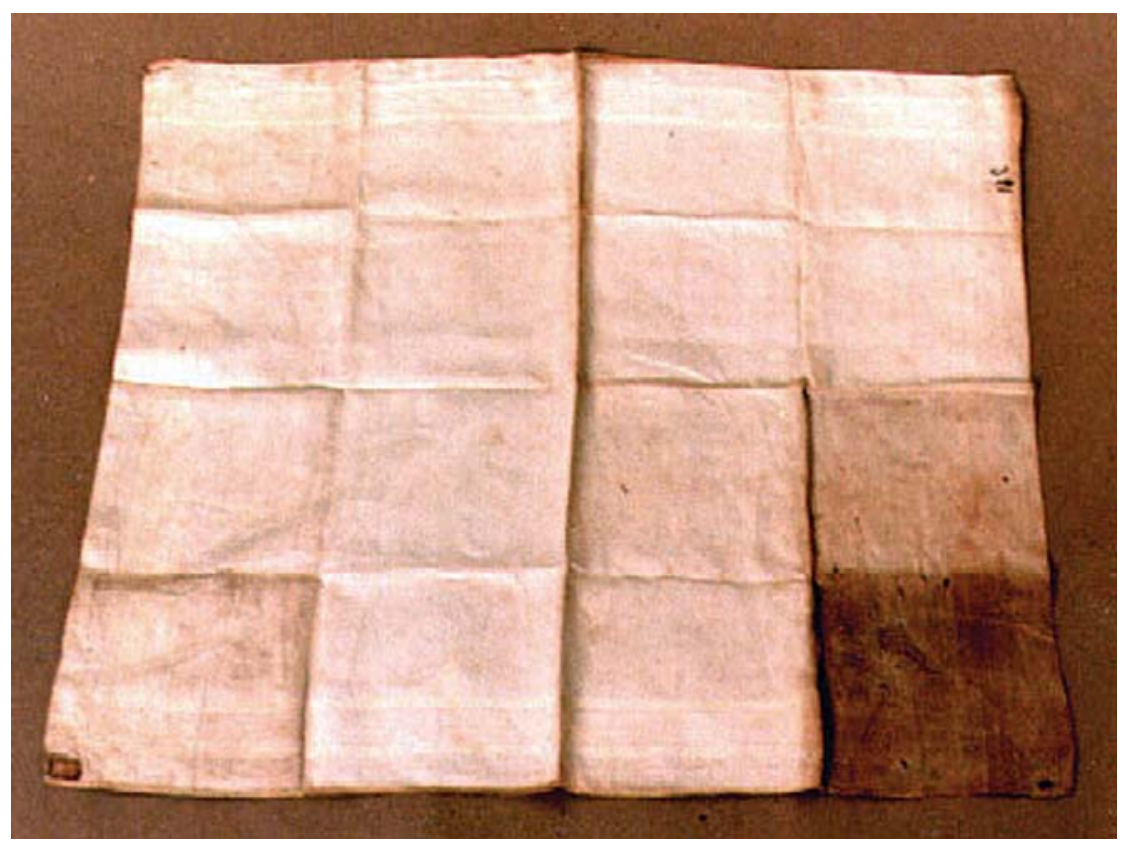

Figura 23 - Lenço em linho que pertenceu a D. Pedro II (RG 279). Note-se que o lenço foi exposto dobrado. A parte mais escura, no canto inferior direito, reagiu sob os efeitos da longa exposição à luz.Acervo do Museu Paulista da Universidade de São Paulo. Fotografia da autora.

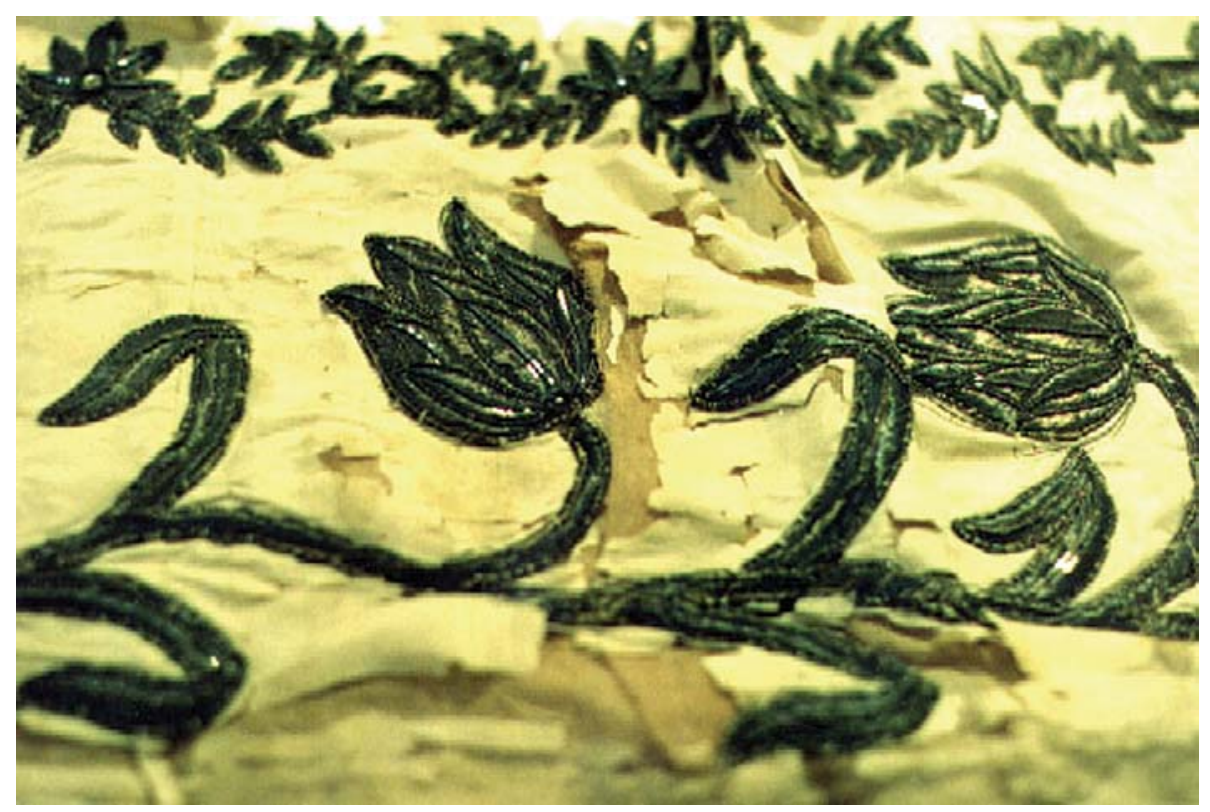

Figura 24 - Detalhe do barrado inferior de vestido de seda com bordados em fios metálicos (RG 1210). O vestido, que pertenceu à Marquesa de Santos, ficou exposto por várias décadas. A ação da gravidade, somada à ação da luz sobre a seda pesada (heary silk) provocou o rompimento do tecido preservado, neste local, devido ao bordado. Acervo do Museu Paulista da Universidade de São Paulo. Fotografia da autora. 


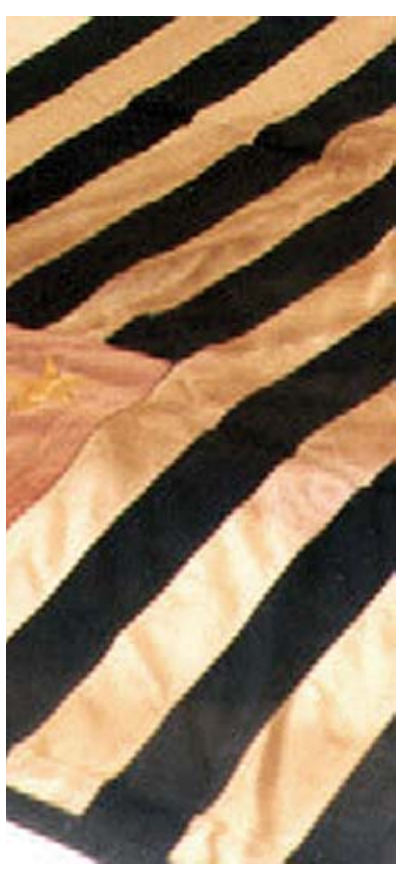

Figura 25 - Bandeira paulista de 1932 (RG 394). As manchas do tecido (escurecimento) foram causadas pela ação da luz. Acervo do Museu Paulista da Universidade de São Paulo. Fotografia da autora.

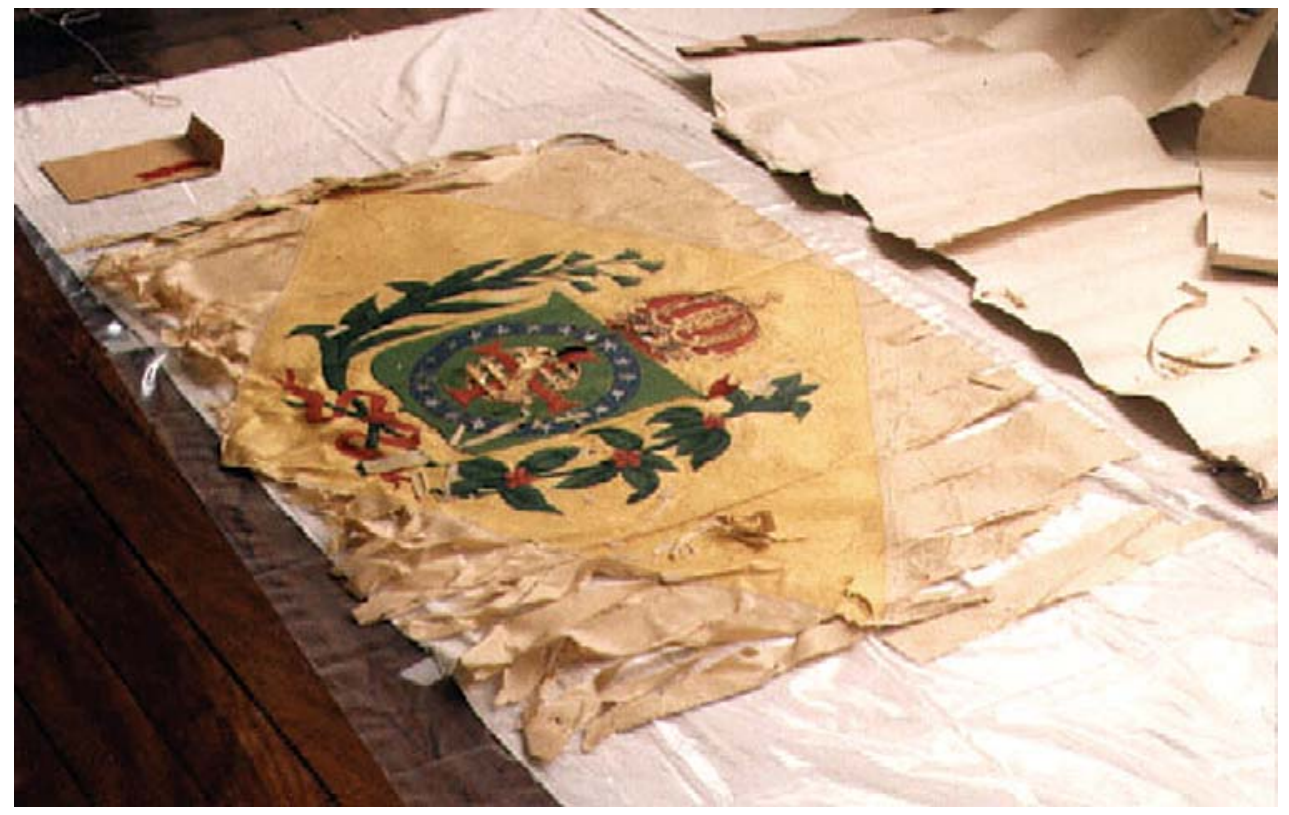

Figura 26 - Bandeira imperial do Brasil (RG 981). Acervo do Museu Paulista da Universidade de São Paulo. Fotografia da autora. 


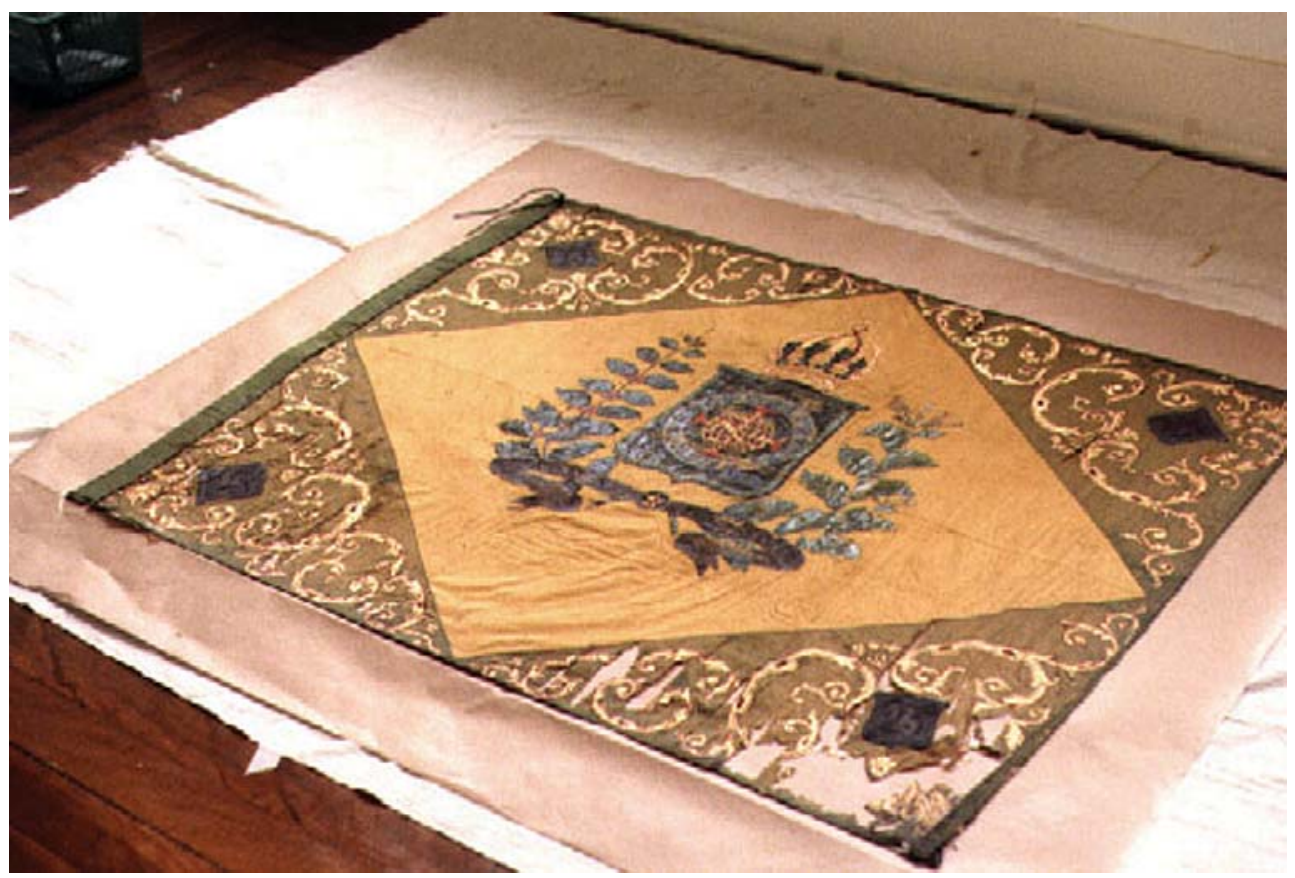

Figura 27 - Bandeira do 25ํㅡㄹatão da Guarda Nacional da Província de São Paulo (RG 975). Acervo do Museu Paulista da Universidade de São Paulo. Fotografia da autora.

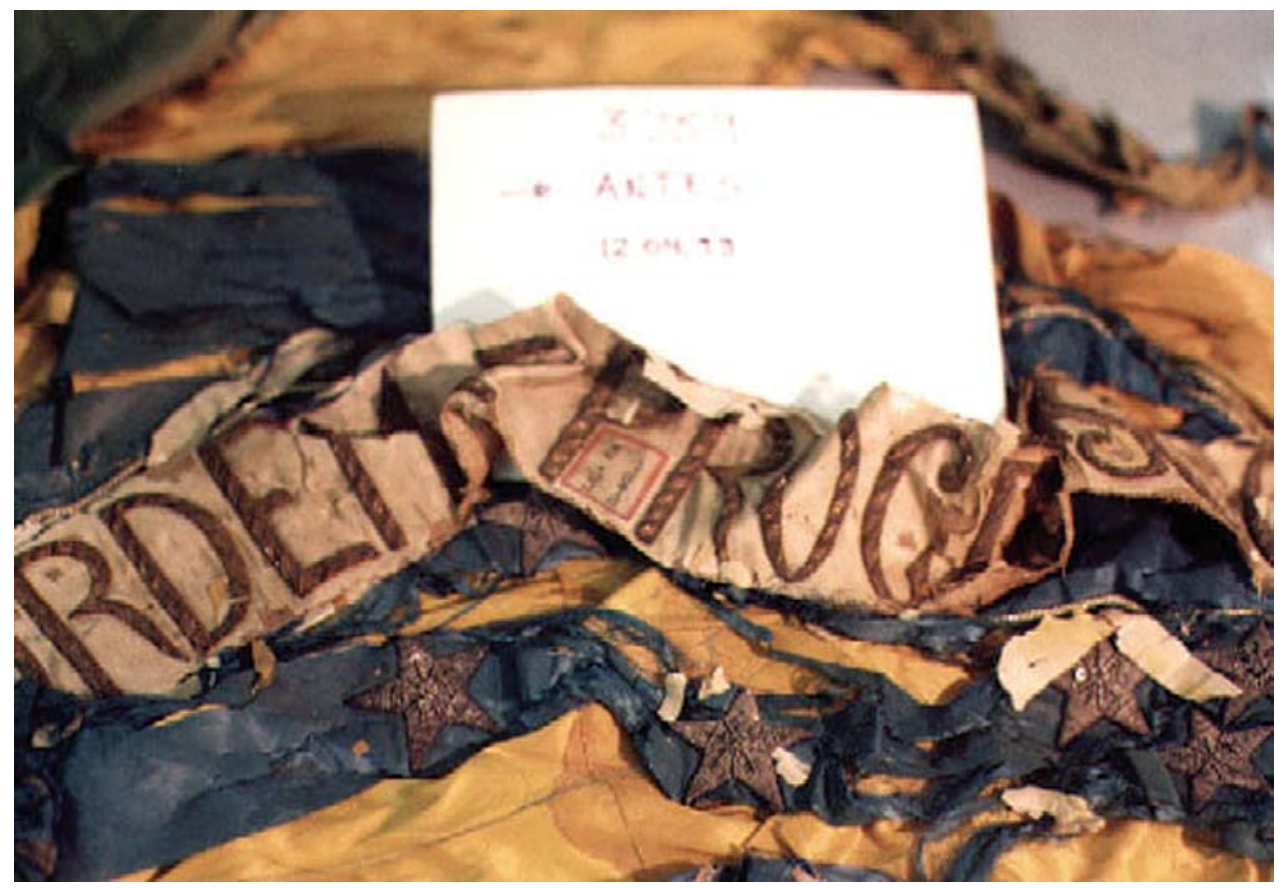

Figura 28 - Bandeira brasileira da república. Acervo do Museu Paulista da Universidade de São Paulo. Fotografia da autora. 
à maioria dos museus de história brasileiros que ainda temem publicar ou sequer registrar tais informações.

Os tecidos que migraram para a Cidade Universitária já apresentavam alguns problemas semelhantes quando ainda residiam no Museu Paulista. O camisão Kaingang (figura 13), mostrado páginas atrás, por exemplo, já apresentava uma grande mancha d'água em sua lateral esquerda. E, como ele, muitos outros tecidos no atual MAE apresentam problemas de conservação. Vários tecidos da coleção Max Uhle são descritos, em 1975, como estando em mau estado de conservação. As condições de conservação do acervo Plinio Ayrosa, por sua vez, foram comentadas em texto de dois conservadores, mas nada foi dito sobre os tecidos no único comentário disponível sobre este acervo ${ }^{23}$.

A superficialidade, portanto, não foi exclusividade da documentação. A conservação também foi pouco comentada nas publicações institucionais. Sobre os tecidos, nada além do citado aqui. Apenas recentemente, tornaram-se assunto de interesse e de estudo permanentes.

Indiferença: tecido também é pintura

How can plastic models with artificial hair, faces and hands ever be "authentic"? On the other hand, how can dress ever look meaningful unless it is displayed on lifelike, periodoriented mannequins posed with the correct stance and hair? (TAYLOR, 2002, p. 41).

Diferentemente do ocorrido no estrangeiro, desde o século XIX, a exposição de tecidos no Brasil também não seguiu as tendências internacionais vigentes. Lou Taylor comenta que as exposições projetadas para o Museu Etnográfico de Estocolmo, inauguradas em 1873, estabeleceram para os museus um padrão expositivo bastante alto, de qualidade. Os manequins do museu sueco, de cabeça e mãos feitos em cera, tinham seus rostos (com olhos azuis, de vidrol perfeitamente modelados por um escultor. $\bigcirc$ encantamento do público e da imprensa foi tal, que, rapidamente, tais modelos se espalharam pela Europa e Estados Unidos. Mas aquela mesma solução adotada para os acervos etnográficos não o seria para outros tipos de indumentária, em outros tipos de museus, sabe-se lá por quais motivos. Na França e na Inglaterra, até a década de 1920, por exemplo, predominaram as exposições que utilizavam manequins sem cabeça. Desde aqueles dias, e sempre, uma acirrada discussão sobre as opções expositivas realismo versus estilização dominou a bibliografia e as práticas museológicas. Mas tal discussão, quase cansativa, ainda não chegou até nós ${ }^{24}$.

Até muito pouco tempo, os tecidos - e os objetos produzidos com tecidos e outros materiais assemelhados - foram expostos sem qualquer peculiaridade nos museus. Em todo o Brasil, as práticas expositivas foram bastante semelhantes até poucas décadas atrás. Museus históricos, antropológicos e "de folclore", endereços mais comuns para os tecidos, adotaram as mesmas e preguiçosas soluções: aqueles tecidos de pequenas e médias dimensões, geralmente, receberam uma moldura e, sob vidros (muitas vezes aderidos), foram
24. Em 2000, Marilia Manzoni Marchi, aluna do Curso de Especialização em Museologia do MAEUSP realizou um levantamento dos manequins utilizados no Museu Paulista discutindo brevemente algumas questões (MARCHI, 2000). 
25. Além da infestação por fungos, geralmente os danos causados são o esmaecimento das cores a adesão das tintas à superfície do vidro, e a ruptura da tecedura no caso de tecidos de seda.

26. Dentre a bibliografia específica sobre mannequinage, a melhor discussão encontra-se em Monier (1994, p.131141). colocados sobre as paredes, combinando com tudo o mais. Esse padrão responsável por uma série de danos aos objetos ${ }^{25}$-, ainda pode ser encontrado em muitos museus brasileiros (Figuras 29 e 30).

As roupas, tradicionalmente, sempre foram vítimas do mau gosto e da falta de senso. Manequins fantasmagóricos, decapitados - com ou sem braços - quase nunca agradaram o público visitante. Ainda hoje, em exposições, predominam soluções visuais ruins e inadequadas do ponto de vista da conservação dos objetos. Aqueles museus que evitaram as formas humanas optaram ou por expô-los na horizontal quase bidimensionalmente, ou adotaram suportes tipo cabide. O problema não é de fácil solução e tem tomado bastante o tempo de profissionais especializados em mannequinage de museus ${ }^{26}$.

Quando as formas estranhas e os volumes exagerados impediram esse procedimento, outras formas criativas e mesmo bastante inusitadas de enquadrá-los, de padronizá-los, foram encontradas. Os tecidos que aparecem expostos na Figura 31 são um curioso exemplo dessa interpretação indiferente.

A imagem anterior e várias outras que se comentarão neste tópico são, todas, acredita-se, de uma mesma exposição do efêmero Museu de Arte e Arqueologia da USP (MAA) - criado em 1964. Os diversos tecidos -

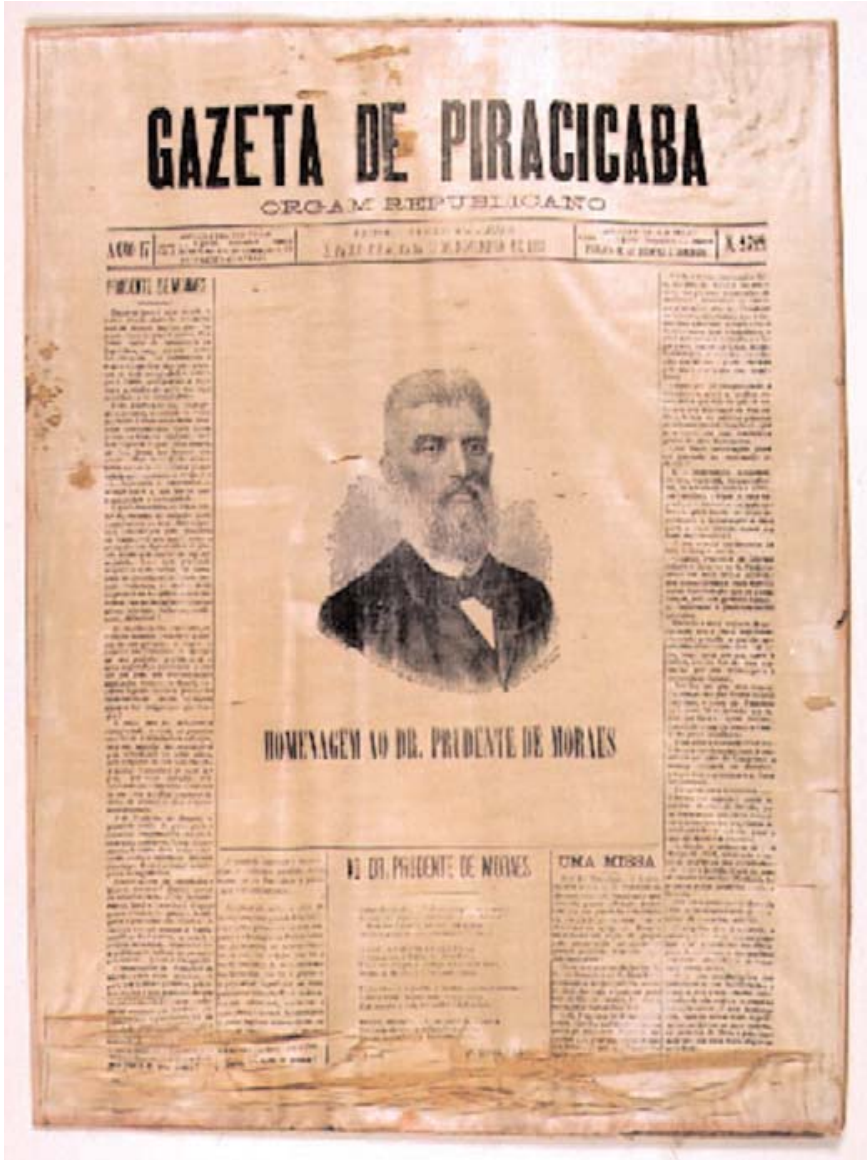

Figura 29 - Imagens (integral e detalhe) da tiragem especial, em tecido de seda, do jornal Gazeta de Piracicaba de 15 de novembro de 1898 (MR 1141 ). O documento que sempre ficou exposto naquele museu foi costurado a máquina, sobre papelão, e inserido em moldura sob um vidro. No detalhe é possível visualizar melhor o estágio avançado de deterioração do tecido de seda. Acervo Museu Republicano Convenção de Itu/USP, Itu. Fotografia de Hélio Nobre. 


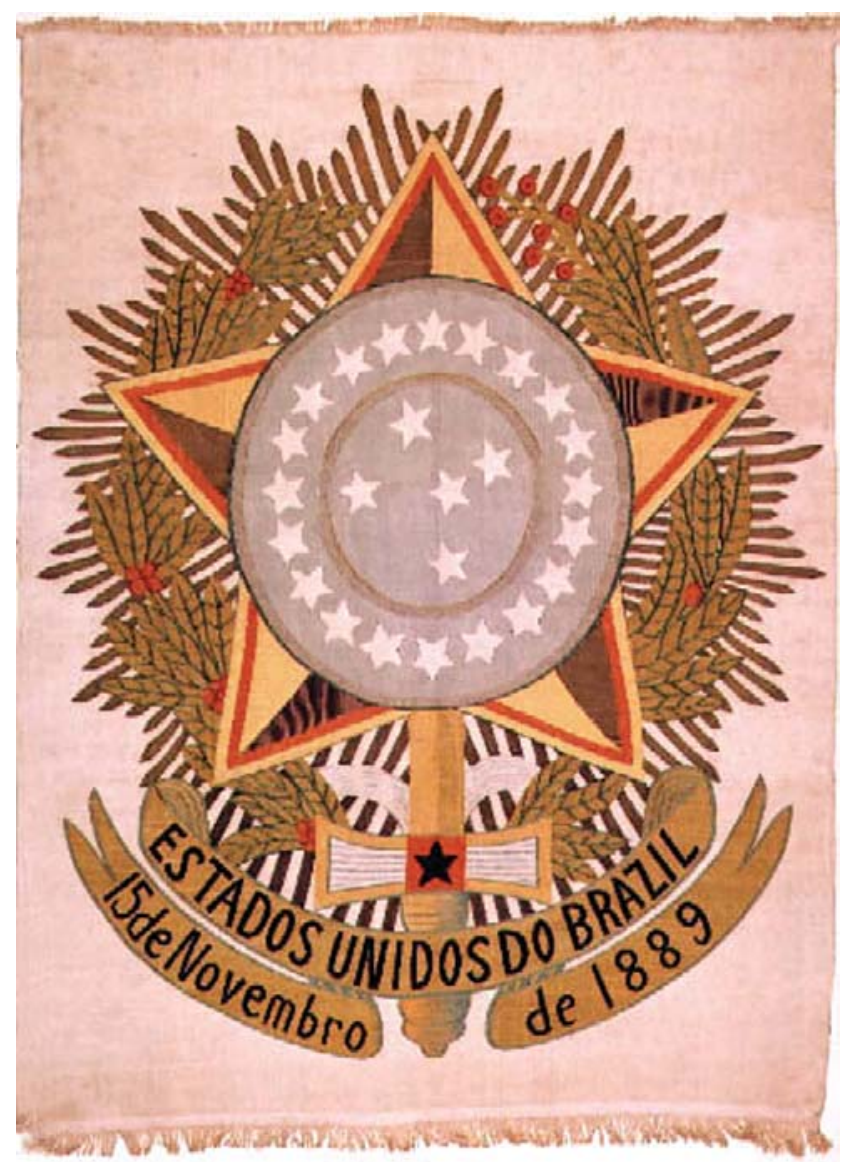

Figura 30 - Imagens (anverso e verso) de brasão da república. Tal qual o exemplo anterior, o Brasão sempre ficou em exposição permanente tendo, conseqüentemente, suas cores esmaecidas. Acervo Museu Republicano Convenção de Itu/USP, Itu. Fotografia de Hélio Nobre.

alguns planos, outros transformados - foram expostos como Arte, ganharam contorno e moldura (Figuras 32 e 33). Se, geralmente, os acervos de índios foram instantaneamente considerados "etnográficos", aqueles procedentes das inúmeras culturas africanas negras foram considerados objetos de Arte (Figura 34).

A indiferença nas práticas curatoriais - indiferença pensada aqui como um tanto faz no lidar com os diversos tipos de objetos - foi um valor predominante em quase todo o século XX. Tal indiferença teve sua provável origem na valoração diferenciada dada aos acervos: alguns objetos, aqueles mais valorizados no mercado de arte, sempre foram considerados mais importantes do que outros objetos. Pinturas de cavalete e esculturas sempre foram as tipologias mais consideradas; depois, o mobiliário e os papéis. E, só então, todo o restante.

Affonso d'Escragnole Taunay destaca, orgulhoso, em seu Relatório de 1920, publicado na Revista do Museu Paulista, as aquisições que fez para a 


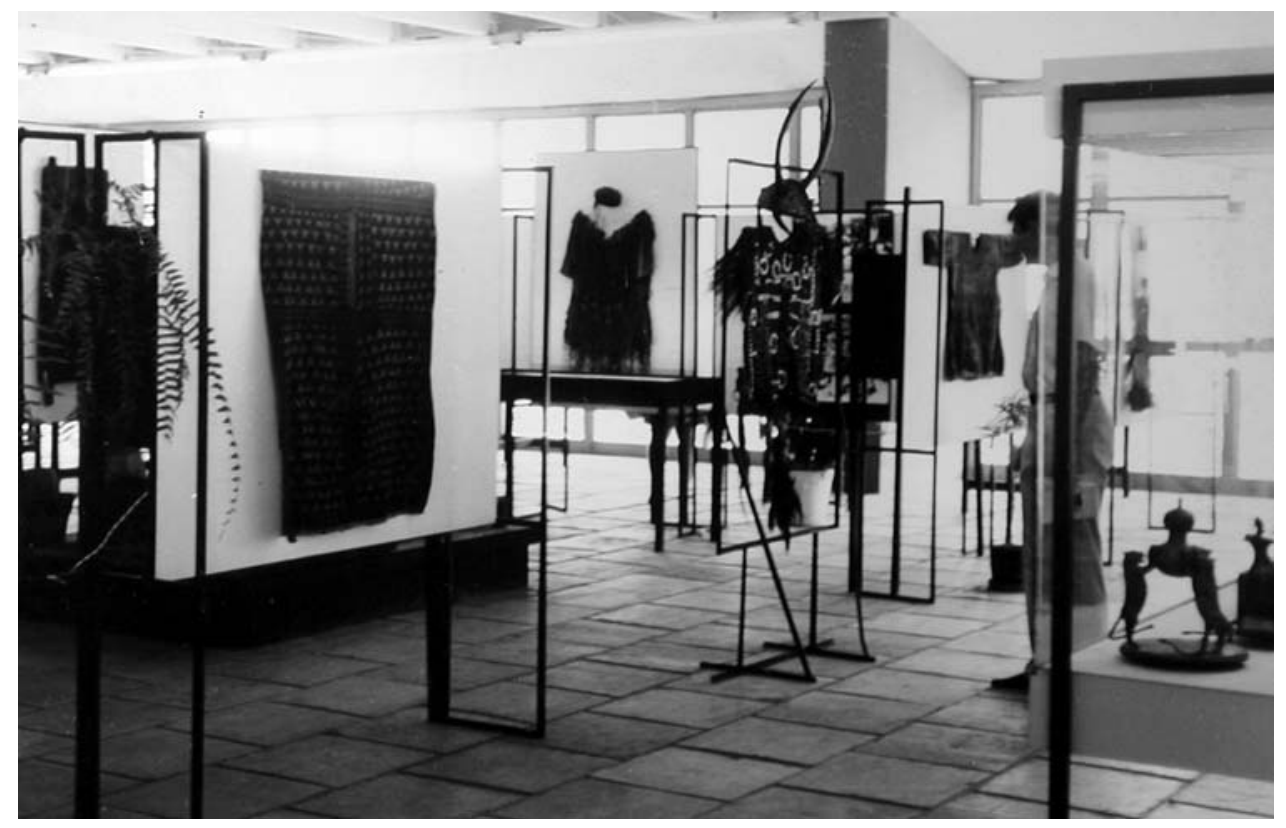

Figura 31 - Vista parcial de exposição do Museu de Arte e Arqueologia. Fołografia, s.d. Arquivo do Museu de Arqueologia e Etnologia da Universidade de São Paulo. Reprodução fotográfica de Wagner Souza e Silva.

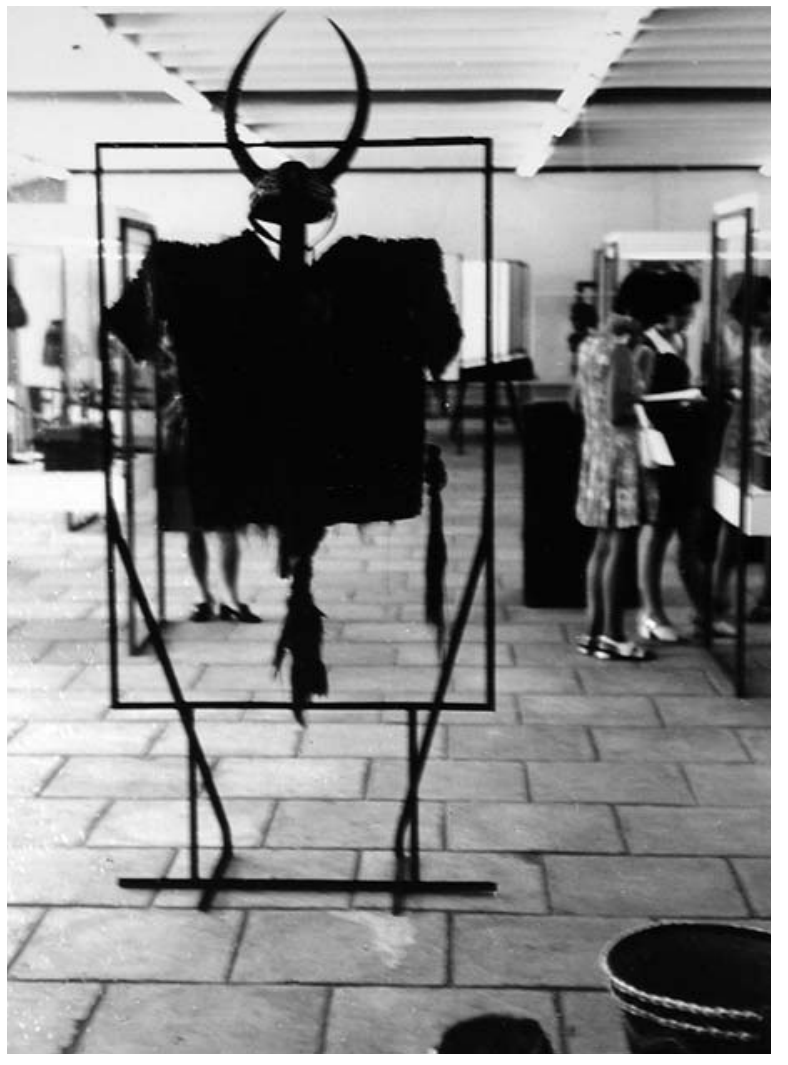

Figura 32 - Vista parcial de exposição do Museu de Arte e Arqueologia. Note-se a solução inusitada para a exposição desse traje. Fotografia, s.d. Arquivo do Museu de Arqueologia e Etnologia da Universidade de São Paulo. Reprodução fotográfica de Wagner Souza e Silva. 


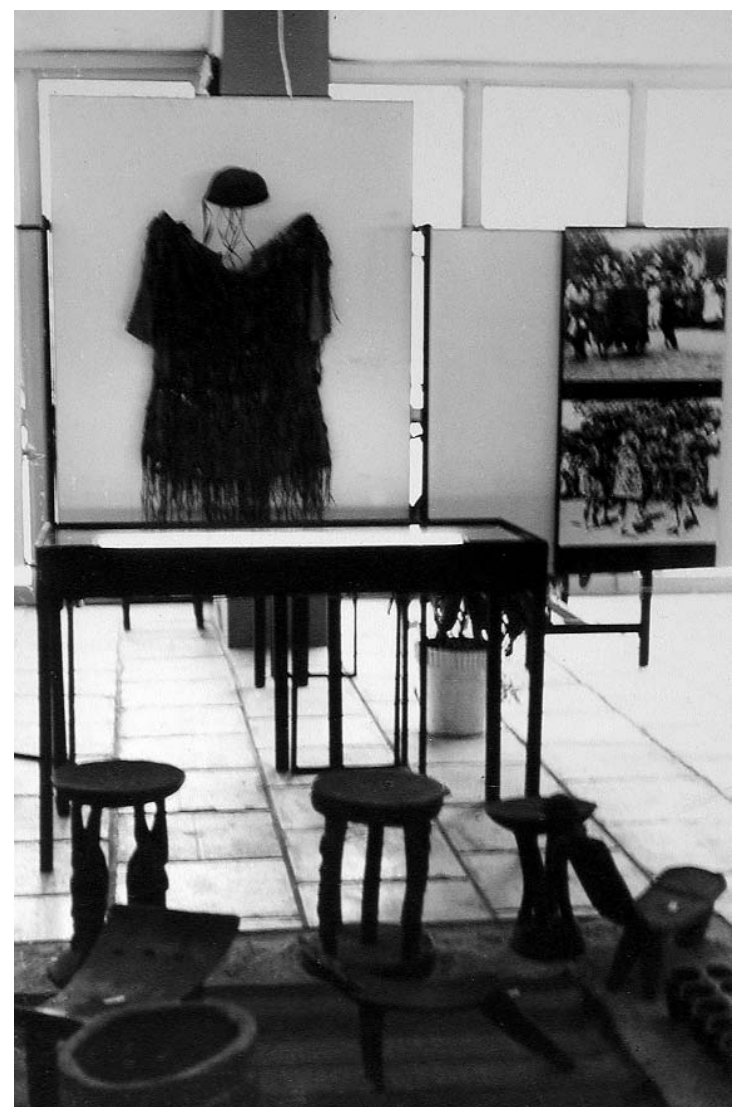

Figura 33 - Vista parcial de exposição do Museu de Arte e Arqueologia. $\bigcirc$ traje, aqui, aparece centralizado no painel, quase bidimensional, quase pintura. Fotografia, s.d. Arquivo do Museu de Arqueologia e Etnologia da Universidade de São Paulo. Reprodução fotográfica de Wagner Souza e Silva.

sala de indumentária - nenhuma delas em tecido - enfatizando, além disso, a encomenda de quatro pinturas ${ }^{27}$ :

Para as salas de indumentária adquiri, entre outras, interessantes collecções de estribos, ferros de engomar, chaves e fechaduras [...] Todos estes documentos iconographicos, agora transportados para a pintura a óleo, obedecem a diversas séries: [...] Sobre indumentária: Senhora rica e sua aia em Porto Feliz; Alvarez Machado e sua familia, em Campinas; Mulheres do povo em dia de festa; Indios mansos de Porto Feliz ${ }^{28}$.

Quase duas décadas depois, em 1937, Taunay - ainda diretor do Museu Paulista - lançou o Guia da Secção Historica do Museu Paulista (TAUNAY, 1937), publicação rica em detalhes, descrevendo cada uma das salas de exposição, fato inédito e que nunca mais se repetiria. Suas descrições mencionavam os grupos de objetos encontrados em cada uma das alas, salas e andares, sempre permeadas por uma ou outra justificativa. As procedências, etnias, sobrenomes, peculiaridades e, algumas vezes, os diferentes materiais, apareceram citados na publicação, muito embora inexista um padrão descritivo comum. Interessam-nos três salas: a sala B-12 Etnographia Brasilica, organizada por Roquette Pinto, onde vários artefatos de fibras (TAUNAY, 1937, p. 103), de diferentes grupos foram organizados nos armários e vitrines; e as salas C-4 Armas

\begin{abstract}
27.As encomendas feitas por Taunay são assunto de discussão de um artigo de Solange Ferraz de Lima e Vânia Carneiro de Carvalho, pesquisadoras do Museu Paulista (CARVALHO; LIMA, 1993, p. 147-178).
\end{abstract}

28. Relatório referente ao ano de 1920. 


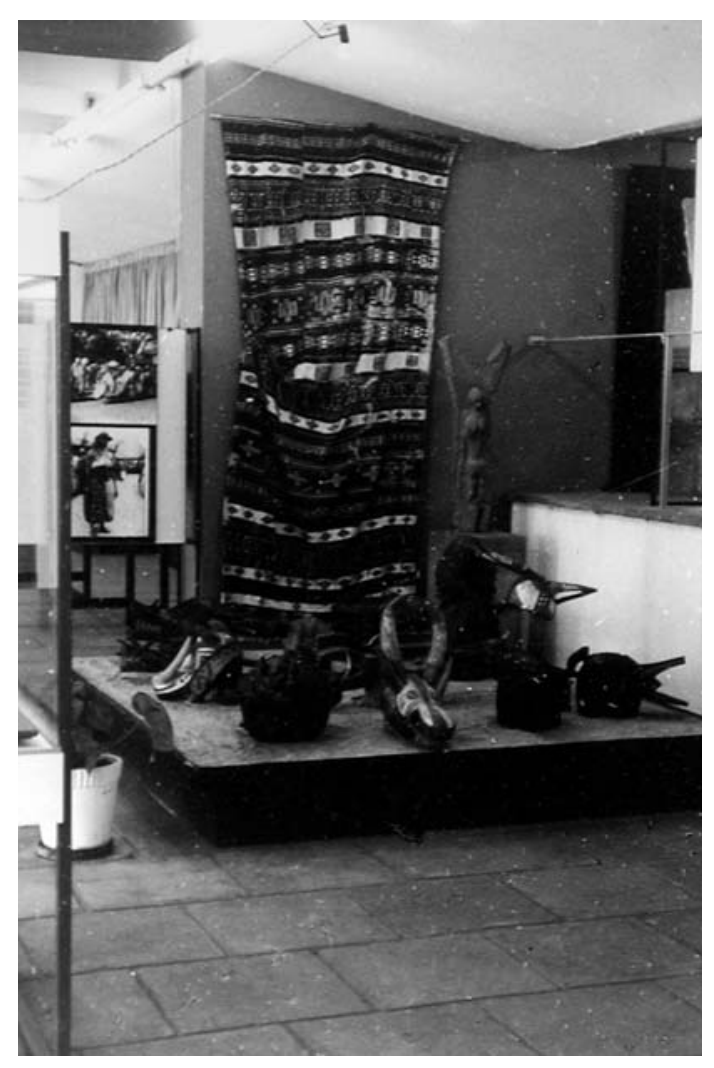

Figura 34 - Vista parcial de exposição do Museu de Arte e Arqueologia. Detalhe do painel mencionado. Fotografia, s.d. Arquivo do Museu de Arqueologia e Etnologia da Universidade de São Paulo. Reprodução fotográfica de Wagner Souza e Silva.
29. Esse padrão expositivo - adotado e copiado por museus de todo o país - ainda pode ser encontrado, por exemplo, em muitas das salas do Museu Nacional, que, felizmente, hoje se encontra em reformulação. e Fardas Antigas-Reminiscencias Militares e C-5 Indumentaria Antiga-FardasObjectos Antigos-Collecções Diversas, onde foram reunidas a indumentária e as fardas antigas de gala (TAUNAY, 1937, p. 1 15), juntamente com algumas bandeiras e estandartes (Figuras 35 e 36$)^{29}$.

Os objetos de índio - a despeito de outras considerações - foram expostos dignamente. As fardas e a indumentária de gala foram suspensas bem alto nos armários, como a sugerir superioridade naquelas pessoas de pequena estatura, a quem as roupas um dia pertenceram. Vestidos de gala ou fardas, isso pouco importava. Apesar de não mais pintadas sobre tela, as roupas, ainda assim, continuaram sendo expostas em duas dimensões, indiferentes a quaisquer especificidades.

Retornemos à exposição do efêmero Museu de Arte e Arqueologia (MAA) para algumas considerações finais sobre este tópico. O Setor Précolombiano da mostra já comentada (Figura 37) também apresentou os tecidos e fragmentos em duas dimensões (Figuras 38 e 39). Mas, aí, há uma diferença interessante, que merece destaque: diferentemente dos tecidos africanos, que eram arte e dispensavam qualquer comentário, os tecidos pré-colombianos arqueológicos - foram acompanhados de pequenos textos explicativos a respeito de sua produção e técnica (Figura 40). Até na indiferença existiu hierarquia, 


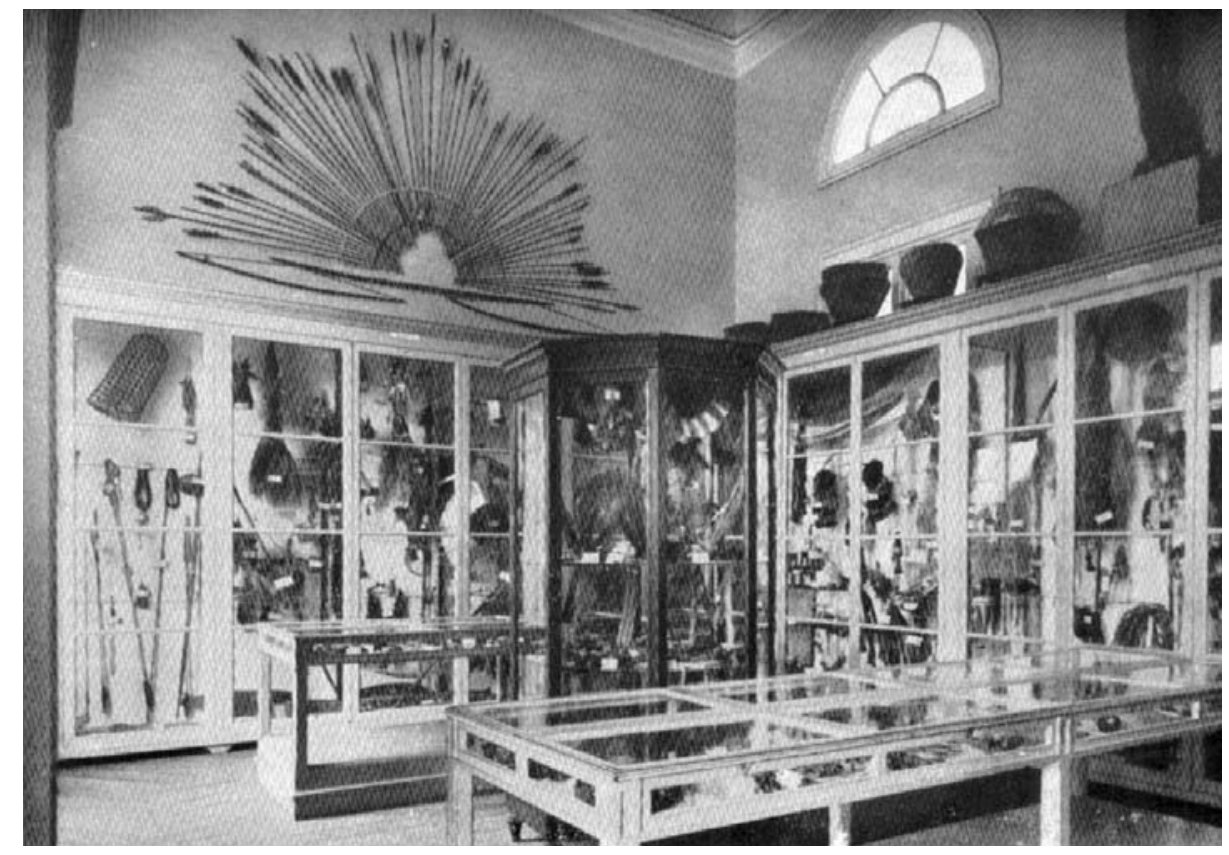

Figura 35 - Imagem de sala de exposição publicada no Guia da Secção Historica do Museu Paulista em 1937, s/n. Acervo do Museu Paulista da Universidade de São Paulo. Reproduzido pela Divisão de Acervo e Curadoria.

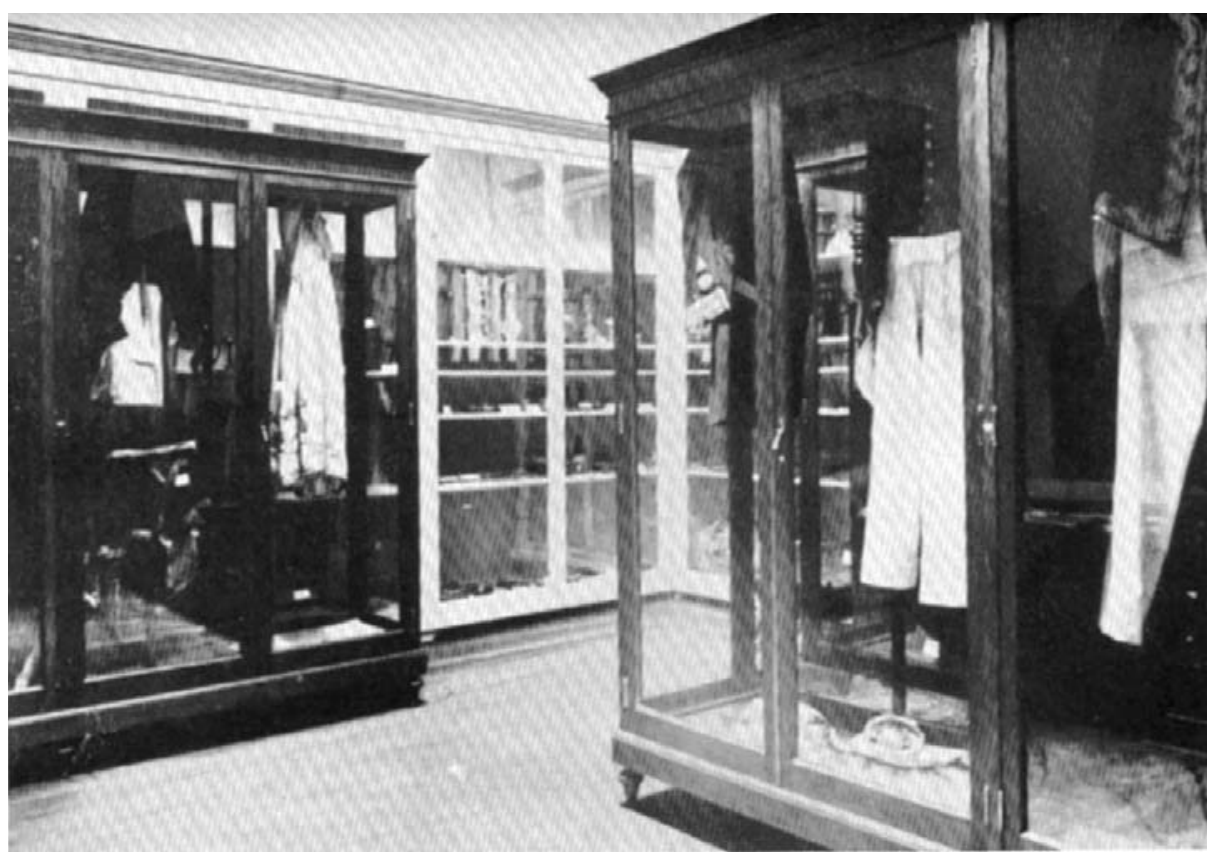

Figura 36-. Imagem de sala de exposição publicada no Guia da Secção Historica do Museu Paulista em 1937, s/n. Acervo do Museu Paulista da Universidade de São Paulo. Reproduzido pela Divisão de Acervo e Curadoria. 


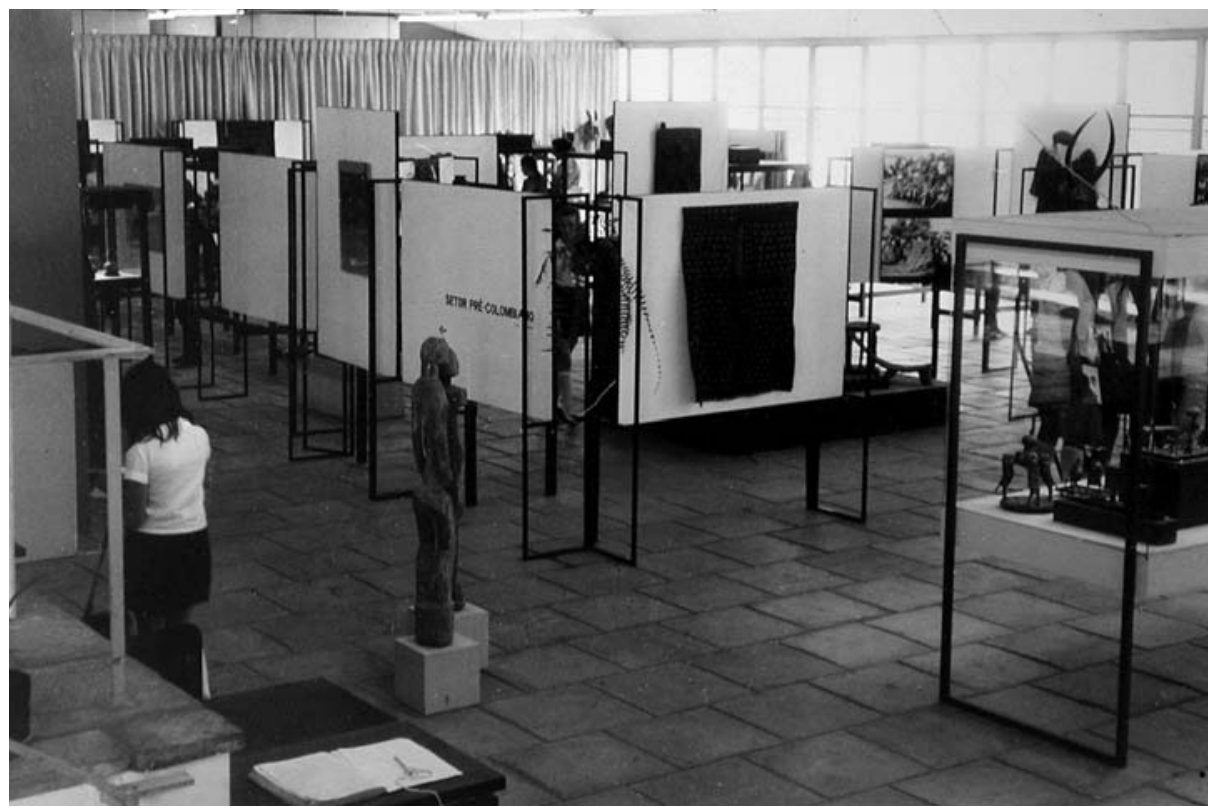

Figura 37-. Vista parcial de exposição do Museu de Arte e Arqueologia. Note-se, à esquerda, o painel com a inscrição Setor Pré-Colombiano. Fotografia, s.d. Arquivo do Museu de Arqueologia e Etnologia da Universidade de São Paulo. Reprodução fotográfica de Wagner Souza e Silva.

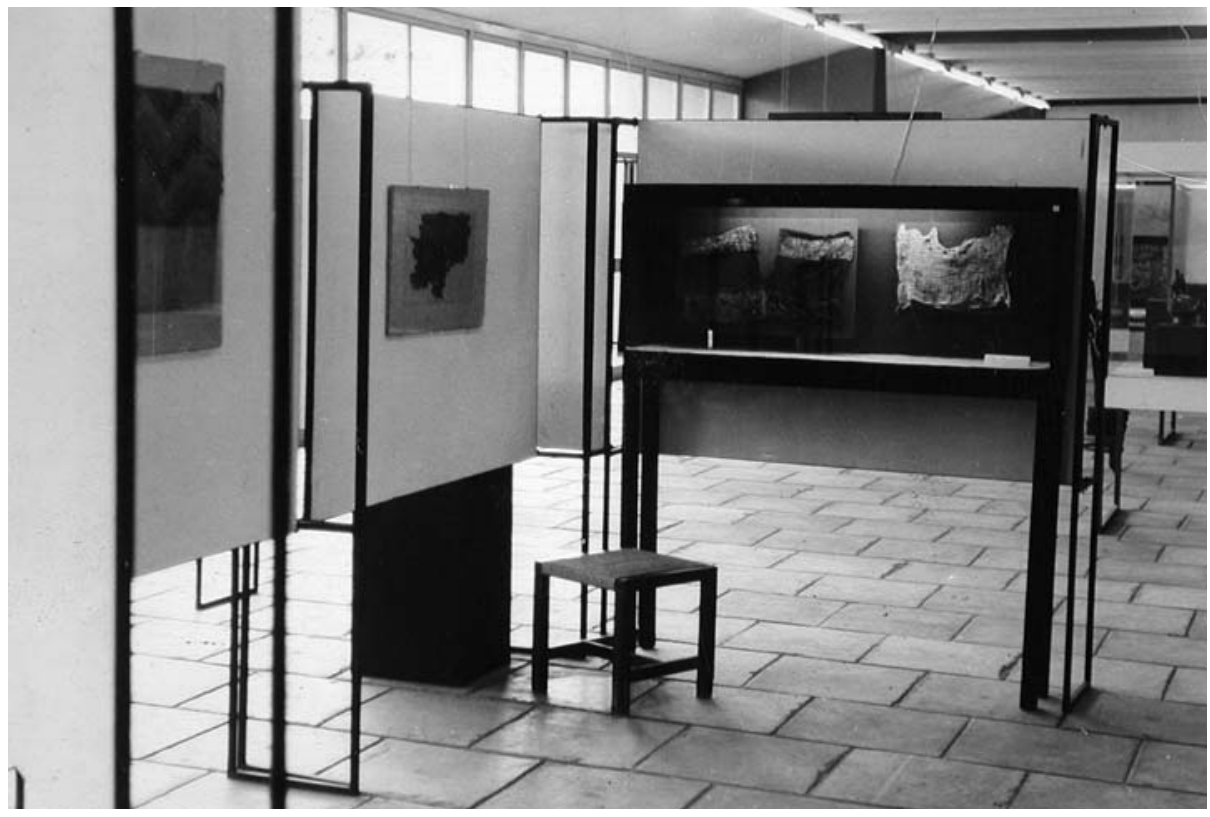

Figura 38 - Vista parcial de exposição do Museu de Arte e Arqueologia. Os tecidos, aparentemente, foram pregados em sua extremidade superior. Note-se a iluminação interna da vitrine. Fotografia, s.d. Arquivo do Museu de Arqueologia e Etnologia da Universidade de São Paulo. Reprodução fotográfica de Wagner Souza e Silva. 


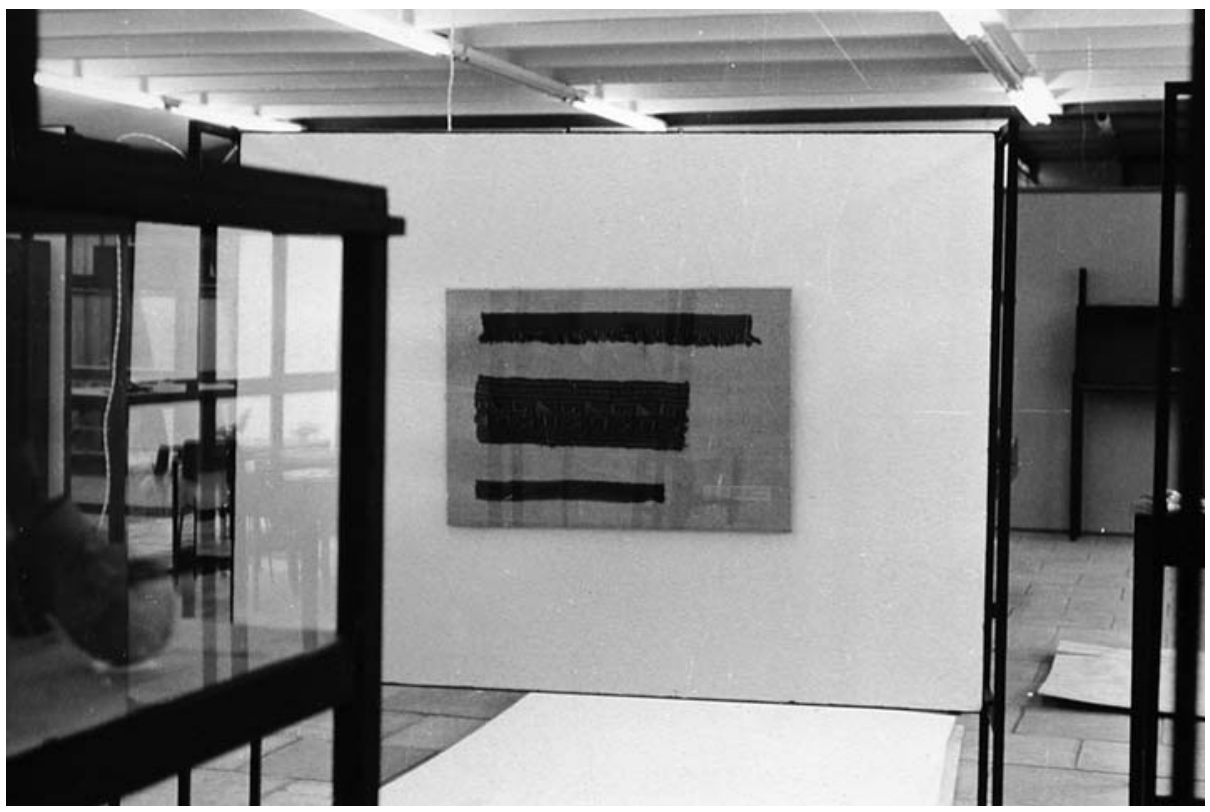

Figura 39 - Vista parcial de exposição do Museu de Arte e Arqueologia. Fotografia, s.d. Arquivo do Museu de Arqueologia e Etnologia da Universidade de São Paulo. Reprodução fotográfica de Wagner Souza e Silva.

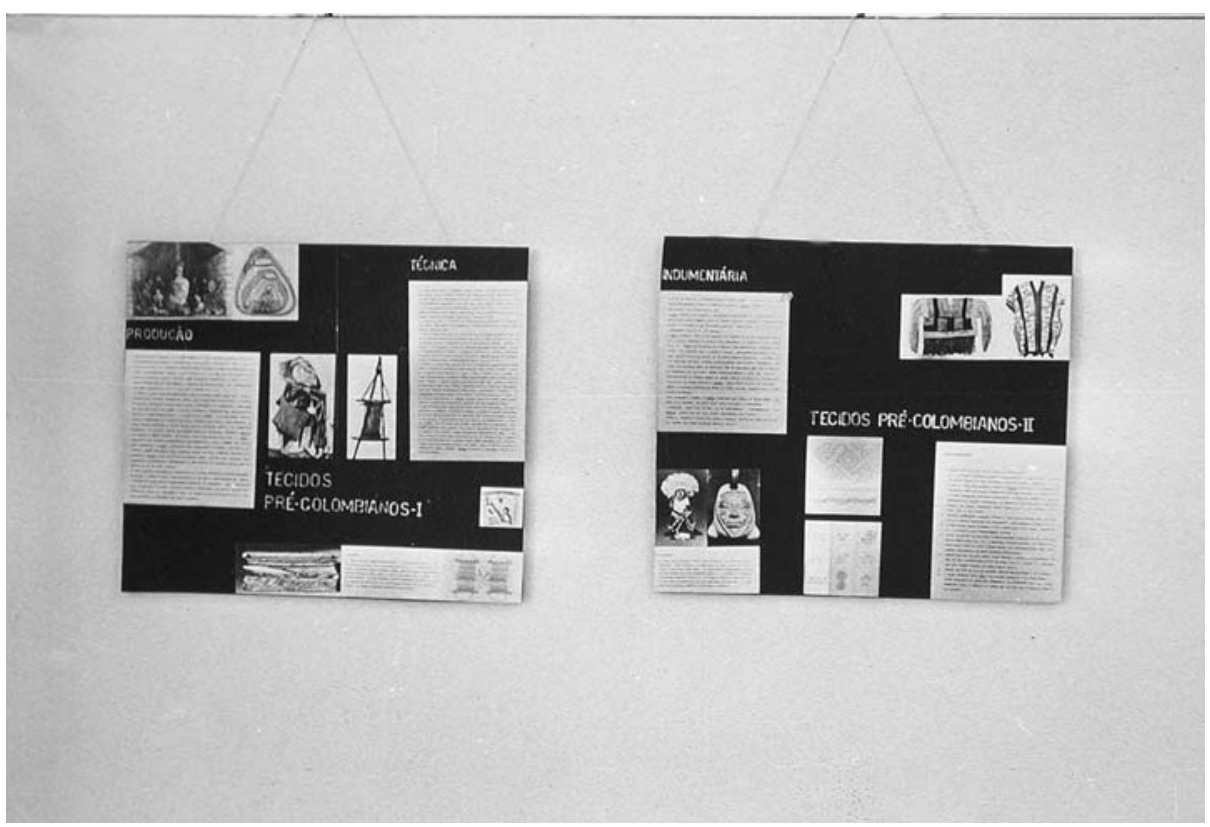

Figura 40-. Vista parcial de exposição do Museu de Arte e Arqueologia. Painéis com textos explicativos sobre Tecidos Pré-Colombianos. Fotografia, s.d. Arquivo do Museu de Arqueologia e Etnologia da Universidade de São Paulo. Reprodução fotográfica de Wagner Souza e Silva. 
existiu valoração. A indiferença foi um valor comum aos objetos em tecido, em diferentes museus, em diferentes décadas, mas, como já afirmamos, alguns objetos foram considerados mais importantes do que outros objetos, numa escala de valores em que, muito provavelmente, os tecidos coptas e os pré-colombianos valiam mais, e os africanos eram os menos considerados. Mesmo no Brasil. Mesmo com a nossa história sendo outra, mesmo com os nossos tecidos sendo outros, as hierarquias do Hemisfério Norte predominaram dentro de nossos museus (e de nossa cultura), também sobre os tecidos.

Exagero: ausência de critérios de coleta

Um grande hiato e acervos numerosos. Esta aparente contradição pode ser considerada a marca registrada do colecionismo institucional nos séculos XIX e XX. Aquisição de grandes quantidades de objetos, lotes, fundos, arquivos, espólios caracterizaram os museus no período. Apesar de proporcionalmente menos numerosos, também os tecidos foram se acumulando nas instituições sem critérios definidos. As publicações do Museu Paulista deixam evidente como as doações sempre foram bem vindas e como a chegada de grandes conjuntos de objetos, provenientes das expedições científicas, sempre foi comemorada. Apesar das queixas constantes a respeito de lacunas numa ou noutra coleção, nunca ficou claro, registrado, o que exatamente se buscava organizar, quais tecidos interessavam e porque eles interessavam.

No estrangeiro, geralmente, dois interesses básicos nortearam a formação das coleç̃ões em tecido. Um primeiro dedicou-se à coleta de tecidos planos e bordados, aliando o registro da tecnologia àquele do gosto e da beleza em um determinado momento. Geralmente nomeados como tecidos decorativos e/ou aplicados, eles foram organizados cronologicamente e, então, por países ou regiões, reunindo os exemplares e os catálogos daqueles produtores considerados como os mais significativos. Assim foram formadas as coleções de Lyon, Riggisberg, Londres, Paris, Quebec e outras já mencionadas. Em 1920, por exemplo, o Museu de Tecidos de Lyon já contava com 552000 tecidos em sua coleção (ARIZZOLI-CLÉMENTEL, 1990, p. 20); e as coleções dos outros museus citados também já somavam, ao final da Primeira Guerra, dezenas de milhares de unidades.

Um segundo interesse voltou-se para a roupa, para o tecido com forma (dress) e seus acessórios. Aqueles museus que se dedicaram à Moda tiveram três critérios básicos para formar suas coleções:

1. As qualidades estéticas da roupa, ou seja, o quanto ela representou - ou não - o melhor uso possível dos elementos disponíveis numa determinada época; 
2. A representatividade da roupa em seu contexto cultural, o impacto e aceitação de seus elementos (tecido, design etc.);

3. $\bigcirc$ bom estado de conservação ${ }^{30}$.

Já os museus etnológicos e etnográficos formaram suas coleções buscando reunir aquelas roupas representativas de uma cultura e das vidas dos indivíduos, do nascimento à morte, em suas atividades familiares internas e externas, em suas atividades profissionais e naquelas de lazer. Ou seja: buscouse reunir coleções significativas e representativas de uma determinada sociedade (REINHAREZ, 1987, p. 192), buscou-se a musealização da vida, a Arca de Noé, com a reunião de, ao menos, um exemplar de cada coisa para cada momento e para cada ocasião ${ }^{31}$.

As roupas coletadas nos museus históricos - principalmente nos Estados Unidos - sempre tiveram como único critério para incorporação às coleções o fato de terem sido usadas por personagens, mais ou menos fictícios, muitas vezes mesclando o barato com a alta costura, a roupa rasgada do herói aos trajes das Primeiras Damas. $\bigcirc$ "critério" mais claro de coleta, dentre todos, sempre foi aquele dos museus arqueológicos europeus aos quais interessavam, sempre, todos os tecidos e assemelhados procedentes das escavações e enterramentos, fossem o que fossem.

As coleções de tecidos que hoje pertencem ao Museu Paulista e ao Museu de Arqueologia e Etnologia nem são tão numerosas assim, quando comparadas a outras tipologias de acervo. $\bigcirc$ exagero do colecionismo refletiuse sobre os tecidos e assemelhados através da falta de critérios de aquisição e formação das coleções, antes e ainda agora. Tudo interessava, fossem um, cinco ou cinqüenta tecidos incas ou uniformes militares: a idéia de coleção, nesses museus, confundiu-se com quantidade, com várias e muitas unidades, pouco importando, por exemplo, qualquer um dos critérios praticados no estrangeiro. Acumulou-se. E acumulou-se mal. $\bigcirc$ colecionismo exagerado materializou a falta de sentido, expandindo o tamanho daquilo que não se preservou.

Discretas esperanças ${ }^{32}$ : a inquietação e os impulsos de mudança

Se as outras cinco tendências associadas às práticas curatoriais até agora estiveram de algum modo salpicadas por pequenas ou intensas negatividades, um sexto e último elemento, a inquietação, talvez possa ser associado somente com movimentações positivas, tais como os impulsos de mudança e/ou tentativas sistemáticas de construir, alterar, indexar, transformar e inventar. Um motor diferenciado, afinal, redentor das práticas curatoriais do milênio passado. Haverá quem discorde, sempre, e certamente por enxergar nos cinco valores citados - instabilidade, superficialidade, impermanência, indiferença e exagero -, as condições necessárias à existência do sexto elemento, a inquietação. Sim e não.
30.Ver Druesedow (1993, p. 4).

31. Sobre os tecidos arqueológicos ver, dentre outros, Wild (1988).

32. Discretas esperanças é título de um livro da filósofa Olgária Mattos, publicado em novembro de 2006. 
Talvez - no passado -, os cinco primeiros valores tenham sido mesmo inevitáveis, necessários a determinados percursos e à eclosão de momentos positivos, inserções criativas e renovadoras nas muitas décadas. Podemos pensar no mundo ou na vida como sendo sempre uma articulação de duas vertentes: a do mundo necessário e aquela do mundo desejado que, quase sempre, é aquele do desconhecido, do não experimentado. A fronteira entre os dois é maleável, elástica, ora avançando ora recuando para um dos lados, mas o fato é que uma vertente precisa da outra, necessariamente ali, ao lado, para continuar existindo. As vertentes são complementares, indissociáveis.

Nos museus e nas atividades patrimoniais, valores como a estabilidade, a exatidão e a permanência pertencem, em teoria, à vertente do mundo necessário. Não são valores opcionais ou secundários, ao contrário, são os valores que fundamentam as práticas institucionais especializadas; são a questão principal da qual dependem os desmembramentos e as intersecções futuras. Deveriam estar ali de antemão, para que a outra vertente, a desejada, fosse exercitada nas práticas curatoriais. Sem essa vertente assegurada, diríamos, a outra corre o risco de ser sempre insatisfatória, apenas uma sucessão de entusiasmos desprovidos de qualquer projeto. Assim considerando, os cinco valores anteriormente citados - dentro do contexto específico dos museus universitários - não foram condição promotora de transformação alguma. A transformação, a inquietude é que, ao contrário, foi uma reação a eles.

Talvez o primeiro sinal de inquietação ${ }^{33}$ tenha sido publicado por Hermann von lhering, já em 1897. Ao comentar a morte de Brown-Goode, diretor do então Museu Nacional dos Estados Unidos, Ihering escolheu registrar as seguintes palavras do colega americano:

Para que um Museu possa ser respeitável e útil deve ser ocupado seguido de atividade agressiva, seja em educação seja em investigação ou em ambas. $\bigcirc$ Museu que não segue uma política agressiva e que não está seguido aumentando e melhorando, não é capaz de ficar com um pessoal competente e com certeza há de cair em decadência ${ }^{34}$.

Limitando a inquietação ao trabalho museólogico com tecidos há um único, mas importantíssimo, momento a se destacar: a publicação inesperada no contexto do Museu Paulista e da Revista, em 1951, - da tese de Gilda de Mello e Souza, A moda no século XIX. Ensaio de Sociologia Estética. A tese abriu o volume 5 da Revista, seguida por textos nacionais e estrangeiros sobre sambaquis, tribos tupis e caboclos amazônicos. Defendida em junho de 1950, a tese foi publicada com vinte e oito páginas de ilustrações - pranchas - o que também não era nada usual. Em suas referências e notas aparecem citados Balzac, Proust, Machado de Assis, José de Alencar e a Revue Française de Psychanalyse, dentre outros. E aqueles que conhecem o texto sabem que ele trata de cores, gostos, tecidos e comportamentos. Tamanha inquietação há de ter gerado reações e controvérsias em toda parte. Se ainda hoje Moda - como assunto e campo de pesquisa - ainda provoca incômodo e desprezo nos meios acadêmicos, imaginemos o impacto causado pela pesquisa em meados do século passado. 
A idéia central deste texto, quando imaginado, era buscar responder a uma simples pergunta: Por que e como os diferentes museus universitários (USP) preservam tecidos? Nossa hipótese sugeria que os diferentes museus buscaram reproduzir localmente, quando de sua criação, os padrões ou modelos institucionais estrangeiros, científicos e/ou acadêmicos. E, assim sendo, trataram de reunir coleções que os qualificassem à projeção nacional ou internacional desejadas, conforme padrões museológicos vigentes no estrangeiro. Aliados a projetos políticos e científicos locais ou nacionais, tais padrões teriam sido adotados como que seguindo um manual imaginário, uma receita: $\bigcirc$ que um bom museu deve conter? E, na resposta, sem dúvida, constava: Um bom museu deve conter alguns têxteis em seu acervo. Acreditávamos, também, que a tal procedimento havia se somado, ainda, o acaso, alguma descontinuidade de critérios, e a sedução do colecionismo como um fim em si mesmo. Todas essas razões juntas, pensávamos, teriam desenvolvido em cada museu especificidades curatoriais e procedimentos de conservação diferenciados que nos interessava então apontar e discutir.

Uma vez compreendida a trajetória das coleções que nos interessavam, tratamos de relacionar, no atual MAE, os objetos têxteis integrantes das diversas coleções. Durante o levantamento unitário do acervo têxtil do MAE, através dos inventários e fichas catalográficas, foi ficando evidente a necessidade de definir e restringir a abrangência do têxtil enquanto tipologia de acervo. As diversas categorias diferenciadoras, pré-estabelecidas para a realização do levantamento, impuseram-nos já uma primeira definição para têxteis, bastante diferente daquela utilizada. A definição até então, adequada às coleções do Museu Paulista e às de museus históricos de modo geral, considerava como têxtil todo e qualquer objeto produzido total ou parcialmente em tecido ou fibras. Esta mesma definição, entretanto, quando aplicada a coleções etnográficas, perde em especificidade e sentido, na medida em que se amplia demais ao abranger, inclusive, coleções predominantemente de outro material - como plumária ou madeira, por exemplo -, que contenham, entretanto, algum elemento têxtil. A necessidade de caracterizar melhor apenas os tecidos levou-nos a uma outra definição, mais específica, que considerava como têxteis apenas os objetos cuja base de sustentação fosse o tecido, ou seja, um produto flexível resultante do entrelaçamento de fios. Com essa alteração, já de início, ficaram intencionalmente excluídos numerosos conjuntos de objetos em plumária, entrecasca e miçangas, basicamente. Nesse novo recorte do assunto a ser estudado, optou-se pelo material, o tecido, matériaprima processada e não mais por uma categoria funcional, tipológica e/ou de posterior utilização. $\bigcirc$ que de início foi tratado apenas como uma mudança conceitual e operacional, digamos, para restringir o levantamento junto ao acervo do MAE, terminou por alterar todo o nosso raciocínio sobre as coleções.

A opção por um material, o tecido, e não mais por uma categoria os têxteis -, todavia, deixou mais evidente a pouca informação e conhecimento 
específico dos indivíduos coletores, pesquisadores ou não, a exemplo do que já havíamos discutido em nosso mestrado em relação ao acervo do Museu Paulista. Em ambos os museus, sempre a identificação das matérias-primas, as técnicas de fiação, tecedura e outras transformações executadas sobre os tecidos foram quase sempre ignoradas pela documentação museológica e pela pesquisa. Freqüentemente, por exemplo, matérias-primas e matérias-primas processadas, ou ainda técnicas e processos, foram nomeados sem qualquer distinção, ou seja: as características específicas dos tecidos enquanto materiais, aquilo que exatamente os qualifica como tecidos, que os diferencia dentre outros materiais - como a entrecasca, a plumária e a cestaria, por exemplo -, foi sempre desconsiderado. Usando um paralelo de uma outra tipologia material que nos é mais familiar, corresponderia a chamar apenas por rocha, e mais nada, a um diamante, a uma esmeralda e a um cristal. Informação vazia. Se a intenção de coleta e exposição dos objetos imitara mesmo os padrões estrangeiros, como pensávamos, como explicar as razões para tal procedimento não se verificar nas respectivas formas de coletar, documentar e estudar aqueles tecidos? Por que os tecidos mereceram tão pouca atenção dentro e fora dos museus?

E foi assim que nossa idéia inicial de discutir exclusivamente as coleções têxteis que hoje integram os acervos do Museu Paulista e do Museu de Arqueologia e Etnologia da USP e suas especificidades curatoriais foi aos poucos se ampliando para uma reflexão das práticas de curadoria no país. Além de discutir o que se encontrava ali, da forma como se encontrava ali, foi preciso também refletir sobre aquilo que não estava ali, sobre o que não fora coletado e preservado, sobre o hiato. A pesquisa que teve início tendo a conservação de tecidos e seus critérios como assunto principal de análise, voltou-se para discutir aquilo que ainda não fora pesquisado e discutido sobre os tecidos: a desinformação e o desinteresse históricos sobre o assunto tornaram-se igualmente relevantes. Afinal, como discutir conservação e critérios de conservação daquilo que não se conhece, que não se discute? $\bigcirc$ tecido, como assunto museológico, desperta tão pouco interesse, que fica mesmo difícil explicar àqueles não especialistas no assunto, a dimensão da falta de informação, o pouco que os acervos preservados informam, o quase tudo que está faltando: a dimensão do hiato. 


\section{REFERÊNCIAS}

ALVES,Ana Maria de Alencar. O Ipiranga apropriado: Ciência, política e poder. O Museu Paulista 1893-1922. São Paulo: Humanitas, 2001.

ARIZZOLI-CLÉMENTEL, Pierre. Le musée des tissus de Lyon. Lyon: Musées et monuments de France, 1990.

BARBUY, Heloisa; LIMA, Solange Ferraz de; CARVALHO, Vânia Carneiro de (Coord). O sistema documental do Museu Paulista: a construção de um banco de dados e imagens num museu universitário em transformação. In: ENCONTRO INTERNACIONAL IMAGEM E CI NCIA, 18., 2002, São Paulo. Imagem e produção de conbecimento. São Paulo: Museu Paulista da Universidade de São Paulo, 2002. p. 13-29.

BEWER, Francesca G. Technical Research and the Care of works of Art at the Fogg Art Museum (1900 to 1950) In: ODDY,Andrew; SMITH, Sandra (Orgs.). Past Practice, Future Prospects. London: The British Museum, 2001, p. 13-18 (Occasional Paper, 145).

BROOKS, Mary M. Textiles Revealed. Object lessons in historic textile and costume research. London:Archetype, 2000

BURNHAM, Dorothy. Warp and Weft. A Textile Terminology.Toronto: Royal Ontario Museum, 1980.

L'art des étoffes. Le filage et le tissage traditionnels au Canadá. Ottawa: Musées Nationaux du Canada, 1981.

CARREIRA,Antonio. Panaria Cabo-verdiano-guineense. Lisboa: Museu de Etnologia do Ultramar, 1965.

CARVALHO, Vânia Carneiro de; LIMA, Solange Ferraz de. São Paulo Antigo, uma encomenda da modernidade: as fotografias de Militão nas pinturas do Museu Paulista.Anais do Museu Paulista, São Paulo, v. 1, 1993, p. 147-178 (Nova Série).

COELHO, Vera Penteado. A coleção Max Uhle. São Paulo: Fundo de Pesquisas do Museu Paulista, 1977.

CONCEPTUAL Textiles. Material meanings. Sheboyan: John Michael Kohler Arts Center, 1996.

DRUESEDOW, Jean L. Introdução. In: (Org.). In Style. Celebrating fifty years of the Costume Institute. New York:The Metropolitan Museum of Art, 1993.

EASTOP,Dinah.Textile as multiple and comparing histories.In:BROOKS, Mary M.Textiles Revealed. Object lessons in historic textile and costume research. London:Archetype, 2000. p. 17-28.

FERREIRA,Alexandre Rodrigues. Viagem filosófica pelas capitanias do Grão-Pará, Rio Negro, Mato Grosso e Cuiabá 1783-1792. Belém: Museu Emilio Goeldi; CNPq, 1983.

GIBERT, Vera Ligia Pieruccini. O entorno acadêmico e industrial têxtil no vestir e morar brasileiros. Dissertação (Mestrado)-Faculdade de Comunicação e Artes, Universidade de São Paulo, São Paulo, 1993. 
HARRIS, Jennifer (Ed.). 5000 years of textiles. London: British Museum Press, 1995.

HEIBERGER, Barbara J. Looking at costume. In:BROOKS, Mary M. Textiles Revealed. Object lessons in historic textile and costume research. London:Archetype, 2000. p. 109-112.

JÁRÓ, Márta et alii. Textiltechnikák. Budapeste: Magyar Nemzeti Múzeum, 1993.

JOHANSEN, Katia. How to read historic textiles. In: BROOKS, Mary M. Textiles Revealed. Object lessons in historic textile and costume research. London:Archetype, 2000. p. 53-66.

LEVEY, Santina M. Fitted for survival; what the selection made by survival reveals. In: BROOKS, Mary M. Textiles Revealed. Object lessons in historic textile and costume research. London: Archetype, 2000. p. 79-88.

LOPES, Maria Margaret. O Brasil descobre a pesquisa científica: os museus e as ciências naturais no século XIX. São Paulo: Hucitec, 1997.

MARCHI, Marilia Manzoni.Bustos e manequins: uma discussão sobre a utilização destes elementos expográficos no Museu Paulista da USP.Trabalho de Conclusão de Curso (Especialização)-Museu de Arqueologia e Etnologia, Universidade de São Paulo, São Paulo, 2000.

MONIER, Véronique. Mannequins et mannequinage: leur incontournable nécessité. In: SFIIC. $L a$ conservation des textiles anciens. Angers: SFIC, 1994. p. 131-141.

O MUSEU Paulista da Universidade de São Paulo. São Paulo: Banco Safra, 1984.

PAULA, Teresa Cristina Toledo de. O tecido como assunto: os têxteis e a conservação nas revistas e catálogos dos Museus da USP. Anais do Museu Paulista: História e Cultura material, São Paulo, v. 13. n. 11, p. 315-371, jan.-jun. 2005.

REINHAREZ, Claudine. Critères de constitution de collection vestimentaires. In: CUISENIER, Jean. Muséologie et ethnologie. Paris: Editions de la Réunion des Musées Nationaux, 1987. p. 186-192.

RIEGL,Alöis. Le culte moderne des monuments. Son essence e sa genèse: Paris: Éditions du Seuil, 1984.

SASS, Sthephen L. The substance of civilization: materials and human history. New York:Arcade, 1998.

SOUSA, Gilda Rocha de Mello A moda no século XIX. Ensaio de Sociologia Estética. Revista do Museu Paulista, v. 5, 1951. [Tese (Doutorado em Sociologia I)-Faculdade de Filosofia, Ciências e Letras, Universidade de São Paulo, São Paulo, 1950]

TAYLOR, Lou. The study of dress history. Manchester: Manchester University Press, 2002.

TAUNAY,Affonso d' E. Guia da seção Histórica do Museu Paulista. São Paulo: Museu Paulista, 1937.

VON IHERING, Hermann. Relatórios. São Paulo: Museu Paulista, 1901 (ms.).

WILD, John Peter. Textiles in Archaeology. London: Shire Archaeology, 1988.

Artigo apresentado em 6/2006. Aprovado em 10/2006. 